\title{
12. Changing Patterns of Corporate Leverage in China: Evidence from listed companies
}

\author{
Ivan Roberts and Andrew Zurawski ${ }^{1}$
}

\section{Introduction}

Since the mid-2000s, Chinese corporate debt has risen sharply as a proportion of gross domestic product (GDP) - from around 100 per cent to over 150 per cent in 2014. By comparison, this ratio is 67 per cent in the United States and 103 per cent in Japan. ${ }^{2}$ Historically, the ratio of debt to income has often been considered a useful indicator for assessing the risk of future banking crises (Borio and Lowe 2002; Drehmann and Juselius 2013). The rapid build-up of debt in China has therefore been increasingly flagged as a risk to financial and macroeconomic stability (Walter and Howie 2011; Pettis 2013).

The rise in corporate debt in recent years has been pronounced for state-owned firms and is frequently attributed to the credit-fuelled macroeconomic stimulus of 2008-09. According to Huang and Bosler (2014: 1), 'the debt surge [was] the result of a deliberate state-driven stimulus program to stave off economic collapse in the aftermath of the global financial crisis'. These countercyclical policies are widely thought to have favoured state-owned enterprises (SOEs) at the expense of the private sector.

In response to rising corporate and government debt, deleveraging has become an explicit focus of macroeconomic policy in China. In late 2015, the Chinese Government listed 'deleveraging' among its structural reform objectives for 2016. In the draft plan for national economic and social development that was delivered to the National People's Congress in 2016, the National Development and Reform Commission (NDRC) observed that 'the debt ratios of enterprises are ... rising; illegal fundraising is becoming more frequent; and hidden financial risks are mounting' (NDRC 2016: 20). The Governor of the People's Bank of China (PBC), Zhou Xiaochuan, has emphasised that to manage overall indebtedness, 'the key is to address the excessive corporate leverage ratio' (PBC 2016).

1 The authors are from Economic Group. The views expressed in this chapter are those of the authors and should not be attributed to the Reserve Bank of Australia.

2 These estimates are based on data provided by BIS (2016) and individual country GDP data. 
This chapter examines trends in the capital structure of more than 2,000 mainland-listed Chinese non-financial companies over the past 15 years and the firm-level drivers of leverage decisions. The patterns in this panel are not necessarily representative of the much larger non-listed corporate sector, for which we lack similarly disaggregated data. Specifically, the total debt accumulated by our sample of listed companies accounts for less than 10 per cent of the broad credit stock in China. ${ }^{3}$ There are also reasons to think that listed firms are special, because, for example, they are likely to be among the better performing mainland firms and have greater access to bank credit and bond or equity finance. Even so, growth in listed company debt or total liabilities has tracked aggregate credit growth reasonably closely in recent years. In addition, certain measures of indebtedness, such as the ratio of listed company debt to earnings, have moved in a manner that is consistent with aggregate estimates of the corporate debt ratio for the Chinese economy.

Nonetheless, a careful examination of listed company data reveals a more nuanced picture than that embodied in conventional narratives surrounding the build-up of debt in China. Our analysis confirms that the leverage of listed state-owned or state-controlled companies ('state firms') has risen relative to that of private firms since the late 2000s. This has been accompanied by a sharp decline in the operating performance of state firms over the same period relative to private firms. The relative trends in leverage for state- and privatelisted firms are especially apparent for the broader measures of leverage that account for rising non-debt liabilities, such as accounts payable and advance receipts. Yet we find that parts of the private sector (particularly firms that have listed since 2008) have also contributed to the rise in leverage. While state firms have continued to account for the bulk of listed company leverage, there is some evidence of deleveraging among the more highly leveraged of these firms. Moreover, the rising share of corporate sector assets in private hands has also contributed to a sizeable shift in the distribution of the increase in listed company leverage towards private firms during the past few years.

By industry, the pattern that emerges highlights the importance of the real estate and construction industries, and particularly state firms in those industries, in driving the rise in corporate leverage since the late 2000s. In part, this reflects the increasing weight of real estate and construction firms, as measured by the proportional value of their assets, in our listed company sample. Outside of the real estate and construction industries, state firms have, in net terms, subtracted from the increase in leverage. By comparison, in manufacturing and services, private firms have tended to contribute positively to the increase in total leverage.

3 We estimate 'broad credit' by subtracting net equity issuance from the PBC's 'total social financing' aggregate, which includes bank loans, undiscounted bank acceptances, entrusted loans (intercompany loans in which a bank acts as an agent) and loans made by trust companies. 
To consider the determinants of leverage at a more disaggregated level, we estimate a range of static and dynamic panel models to help explain leverage among Chinese-listed firms. We augment these models with additional dummy variables to control for macroeconomic influences on corporate leverage. In so doing, we update and extend earlier studies of Chinese corporate leverage that use smaller, shorter panels (Chen 2004; Qian et al. 2009).

The results from static fixed-effects models highlight a negative relationship between leverage and profitability and a positive correlation with firm size, collateral and industry leverage patterns as significant influences on leverage at the firm level. Consistent with the idea that the 2008-09 stimulus was disproportionately directed at state firms, these models show that state sector leverage (measured by the liabilities-to-assets ratio) increased relative to private sector leverage after 2008, when we account for firm-level determinants of capital structure. Dynamic models, which allow for leverage decisions to be correlated over time, further show that persistence in capital structure decisions at the firm level is an important driver of observed leverage behaviour. This feature, together with declining profitability among state firms and the shift in industry composition towards more highly leveraged sectors, such as real estate and construction in the wake of the stimulus, may help to explain much of the upward trend in leverage in recent years. We argue that if this is correct, sluggish adjustment in firm behaviour could make it challenging for China's corporate sector to achieve rapid deleveraging.

Our work complements recent contributions by Chivakul and Lam (2015) and Zhang et al. (2015), who use different datasets and modelling strategies to consider related questions. Employing a panel that includes Hong Konglisted Chinese firms, Chivakul and Lam (2015) estimate pre-2009 and post-2009 static models of leverage and find that state ownership increased leverage in the post-stimulus period (consistent with our own results for static models). They also analyse the vulnerability of state-owned and private sector firms to increases in borrowing costs and emphasise the possible spillovers from financial distress in the real estate industry to the corporate sector as a whole. Zhang et al. (2015) emphasise implicit government support and widespread corporate credit intermediation as key reasons for rising indebtedness among listed stateowned firms. Using a sample of listed firms and bond issuers over the period 2009-13, they estimate the elasticity of financial assets to liabilities as a proxy for corporate credit intermediation, and find that it is higher for SOEs than for the private sector firms. By comparison, we focus on a detailed decomposition of leverage patterns by industry and firm type and explore the implications of models that allow for dynamic capital structure decisions at the level of the individual firm. 
The chapter proceeds as follows. The next section discusses trends in aggregate corporate debt in China and provides a comparison with the evidence from listed companies. Section three undertakes a decomposition of listed company leverage to consider in detail the main compositional drivers after 2008. Section four describes the data and empirical strategies we use to consider the firm-level determinants of leverage, and quantifies the degree of persistence in capital structure decisions, and section five concludes.

\section{Recent trends in Chinese corporate debt and leverage}

The debt of non-financial companies in China increased rapidly in the wake of the Global Financial Crisis (GFC) and has accounted for most of the increase in economy-wide indebtedness since 2008 (Figure 12.1). Although official statistics are not available at a sectoral level, Bank for International Settlements (BIS) estimates suggest that non-financial corporations' debt grew by more than 30 per cent in year-ended terms in 2009 and that growth has averaged almost 20 per cent since 2010. Other estimates, such as official broad credit aggregates ('total social financing' adjusted for lending to households and equity issuance by corporations), show similar trends. Although there is debate regarding the extent to which lending after 2008 favoured state-owned firms rather than the private sector, bank lending to SOEs is widely assumed to have been an important driver of the rapid growth of credit during this period (Lardy 2012).

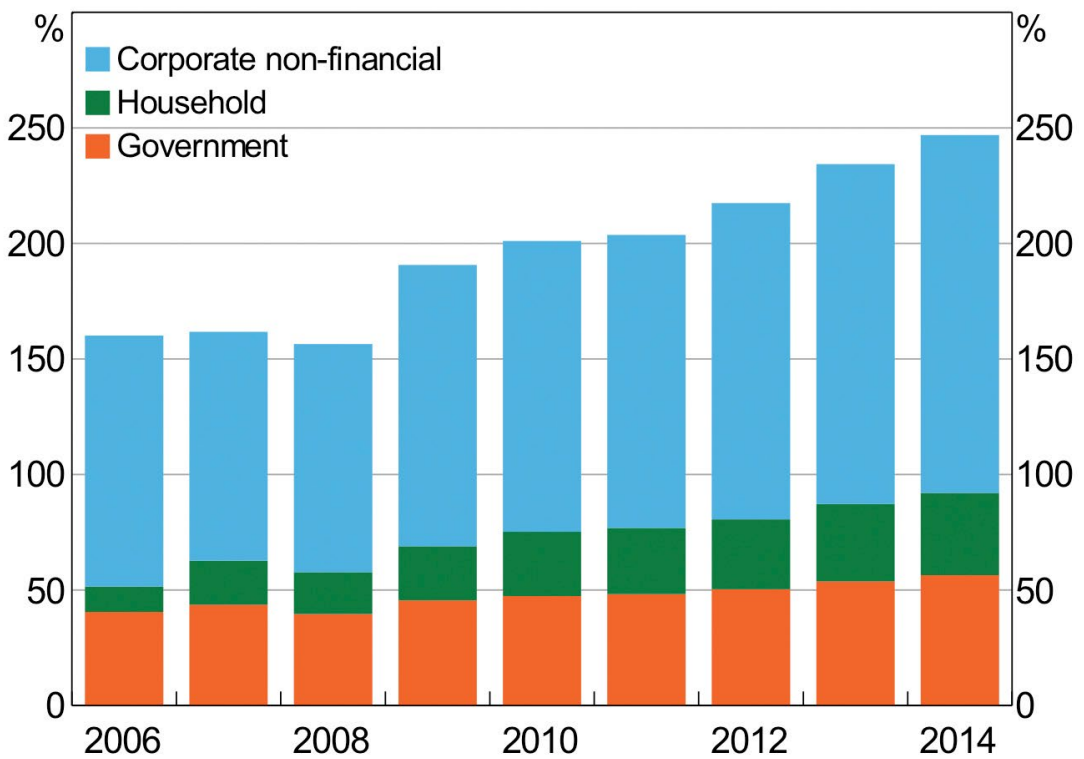

Figure 12.1 China: Ratio of debt to GDP by sector 
The BIS estimates suggest that non-financial corporations' debt was slightly less than 100 per cent of GDP in 2008 and increased to more than 160 per cent of GDP by mid-2015. This has led to concerns about the sustainability of the debt build-up, with some analysts arguing that 'China has become indebted before it has become rich' (Chen 2014: 3).

A feature of China's non-financial corporate debt is that it is primarily domestically owned. Although Chinese corporations have issued foreign currency-denominated bonds in sizeable volumes in recent years, the use of cross-border funding remains relatively low, accounting for around 10 per cent of total non-financial corporate debt by the end of 2014. The low use of external funding in part reflects China's large and persistent current account surpluses and high saving rate. These features set China apart from many other emerging economies, for which foreign currency-denominated debt accounts for a sizeable share of overall corporate debt (Figure 12.2).

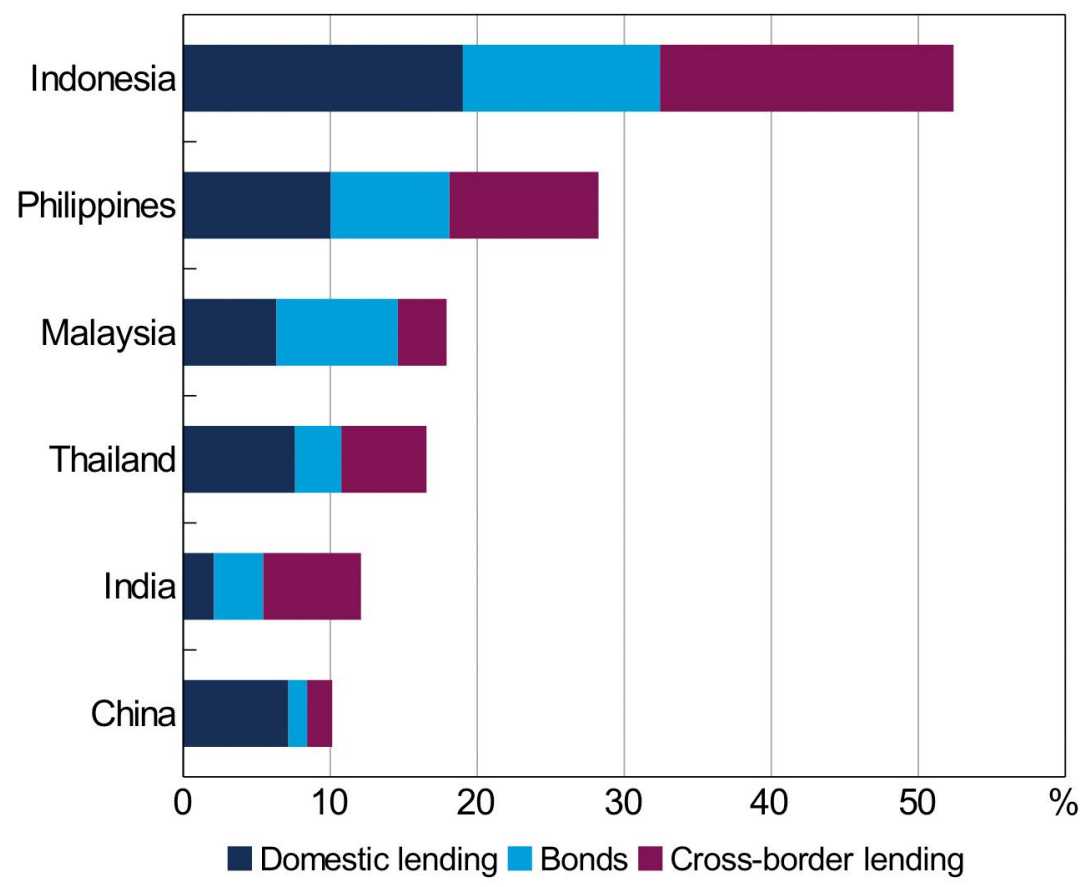

Figure 12.2 Emerging Asia non-financial corporate debt (foreign currency denominated, percentage of total), 2014

Source: IMF (2015b).

While the low use by Chinese firms of offshore funding reduces their exposure to rapid exchange rate movements, the continuous upward trend in the corporate debt to GDP ratio has been flagged as a risk to financial and macroeconomic stability by both Chinese policymakers and private sector analysts. One concern 
stems from the fact that, if recent trends in broad credit creation are sustained, it is unlikely that the debt-to-GDP ratio will stabilise or fall in the next one to two years. Real economic growth has been moderating, inflation pressures are subdued (exemplified by the decline in the GDP deflator in 2015) and credit growth remains strong. Official government targets tabled at political meetings in March 2016 project growth in real GDP of 6.5 to 7 per cent in 2016 and growth in the stock of total social financing - a measure of broad financing to the real economy - of 13 per cent. If these targets are realised, the upward trend in the aggregate debt-to-GDP ratio is likely to continue for at least another year. In fact, without a significant increase in nominal GDP growth, credit growth would need to fall dramatically for the current trend to be reversed.

These debt aggregates, however, reveal little about the changing composition of leverage. Even the distinction between 'non-financial corporate' debt and 'government' debt in Figure 12.1 cannot be defended too strongly, due to the importance of SOEs - centrally controlled SOEs in particular - as agents of official policy. The figures are also silent on variation at the industry level.

\section{Evidence from industrial surveys}

Official data drawn from industrial surveys provide some insight into changes in indebtedness by ownership and by industry. The National Bureau of Statistics of China (NBS) publishes aggregate data on the balance sheets of industrial, real estate and construction enterprises. ${ }^{4}$ For comparison with the statistics corresponding to the whole economy, we calculate the ratio of total liabilities to earnings before interest and tax (EBIT) for these industries. ${ }^{5}$ This metric similarly expresses the stock of liabilities as the ratio of an income flow and provides a gauge of how sufficient current cash flow is to service the existing stock of liabilities. Compared with the economy-wide debt-to-GDP ratio, the NBS data indicate a slight increase in the liabilities of the industrial and construction sectors relative to revenue in the past few years, alongside a particularly sharp pick-up in the same ratio for real estate post-2008 (Figure 12.3).

Another way of assessing the extent of non-financial firms' indebtedness is to measure leverage. Leverage can be defined in a variety of ways, but it is usually measured as debt or total liabilities (debt plus non-debt liabilities) as a ratio to assets or equity. Similar to the liabilities (or debt) to EBIT ratio, and all other things being equal, a higher leverage ratio can signal greater vulnerability,

4 These data are compiled from surveys of all state-owned and non-state-owned enterprises with revenue from principal business of more than RMB5 million from 1998 to 2006; from 2007, all enterprises with revenue from principal business of more than RMB5 million are also included; and since 2011, only enterprises with principal business revenue exceeding RMB20 million have been included.

5 We use total liabilities rather than debt, as figures for the latter are not available. 
as this implies that a firm's reliance on external financing may exceed its ability to pay down debt principal through the sale of existing assets. Of course, increases in aggregate leverage in an economy might also reflect other factors that lead to industries with higher relative leverage becoming more important in the economy, such as changes in industry structure.

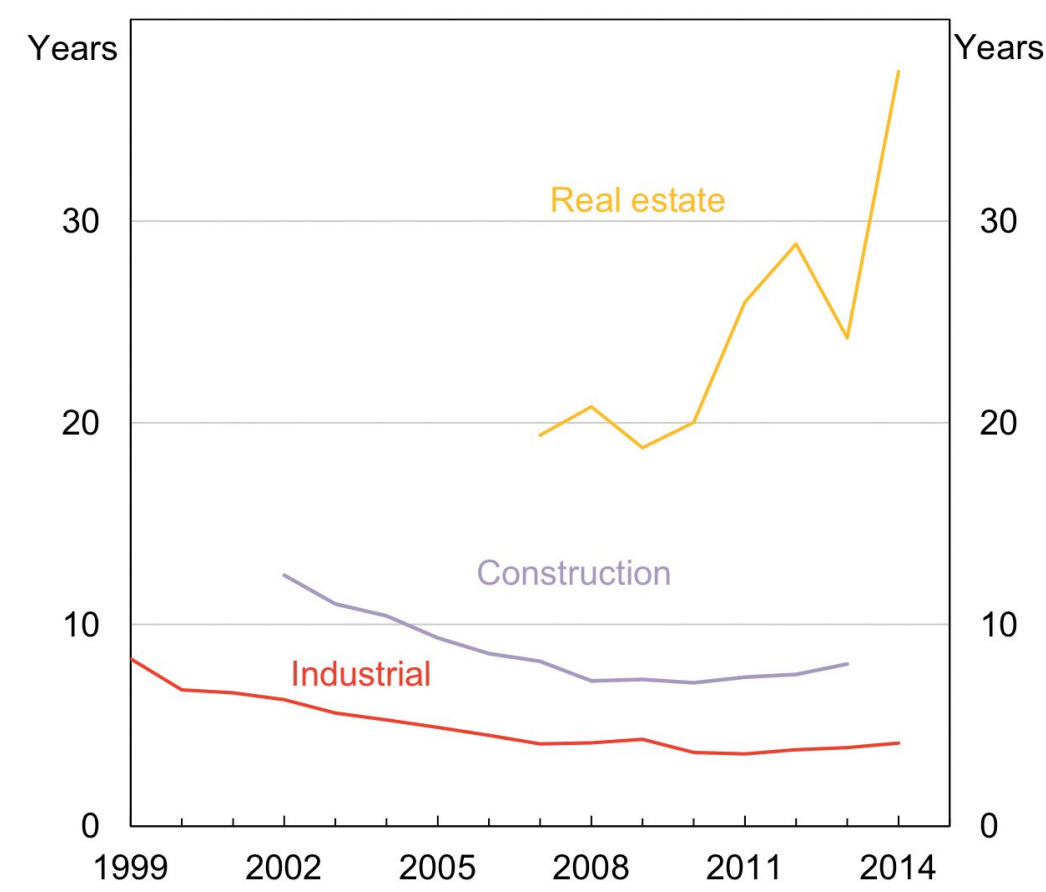

Figure 12.3 China: Liabilities by industry (ratio to EBIT)

Note: Data are available to 2015 for industrial firms, to 2014 for real estate firms and to 2013 for construction firms.

Sources: Authors' calculations; CEIC Data.

The NBS data suggest that corporate leverage, measured by the ratio of liabilities to assets, has varied by sector and by ownership (Figure 12.4). These data indicate that since the mid-2000s, leverage has generally been lower for privately owned industrial and construction firms than for state-owned or statecontrolled enterprises, and that the latter have experienced rising leverage. ${ }^{6}$ However, in the case of the real estate sector, the data suggest that state real

6 The 'state-owned and state-holding' classification is used to define SOEs in the NBS data. These are enterprises for which all assets are owned by the state or mixed ownership enterprises where the percentage of the state shareholding is larger than that of any other single shareholder. Private firms are calculated as the residual of the total less 'state-owned and state-holding'. 
estate companies have reduced their leverage steadily in recent years, whereas there has been substantial growth in both the assets and the leverage of private real estate firms.

The relative increase in the leverage of state industrial firms has coincided with a deterioration in their profitability relative to private firms as measured by profits as a share of assets (Figure 12.5). For the construction and real estate industries, the data suggest that private firms have been consistently more profitable than SOEs. Private sector profitability across the sector for which data are available has fallen in recent years, but remains above the level for the broader corporate sector.

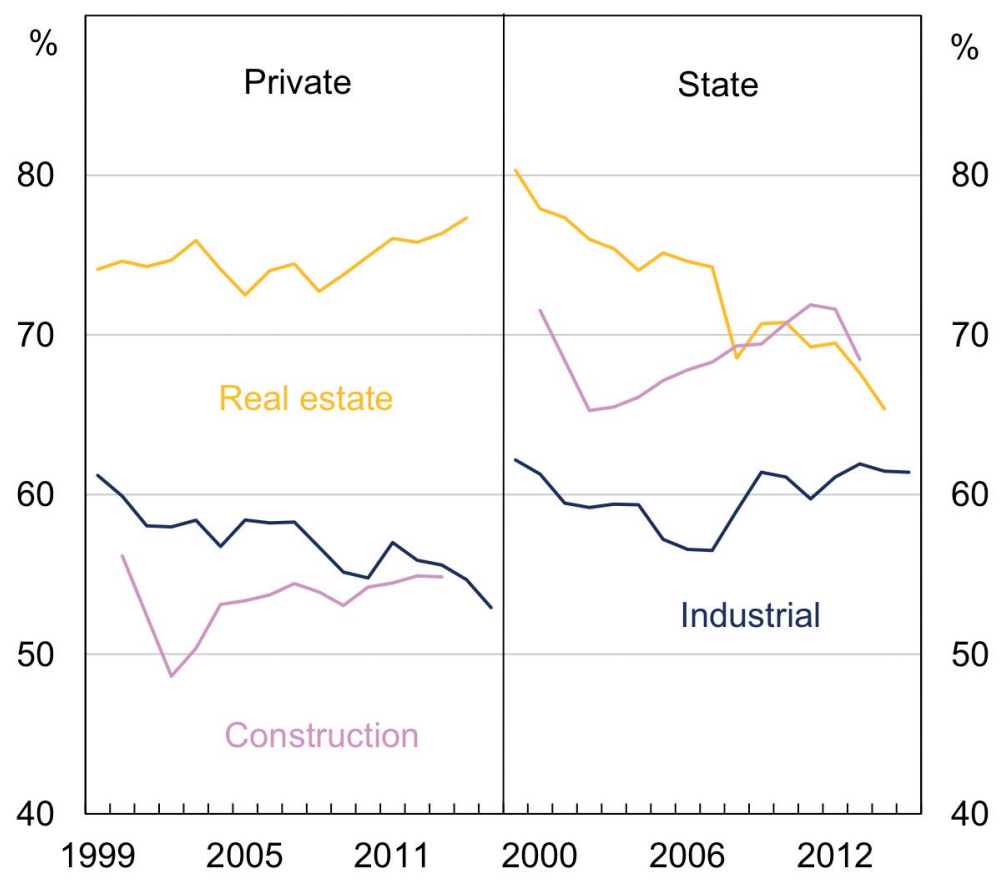

Figure 12.4 China: Corporate leverage by industry and ownership/control (ratio of liabilities to assets)

Note: Data are available to 2015 for industrial firms, to 2014 for real estate firms and to 2013 for construction firms.

Sources: Authors' calculations; CEIC Data. 


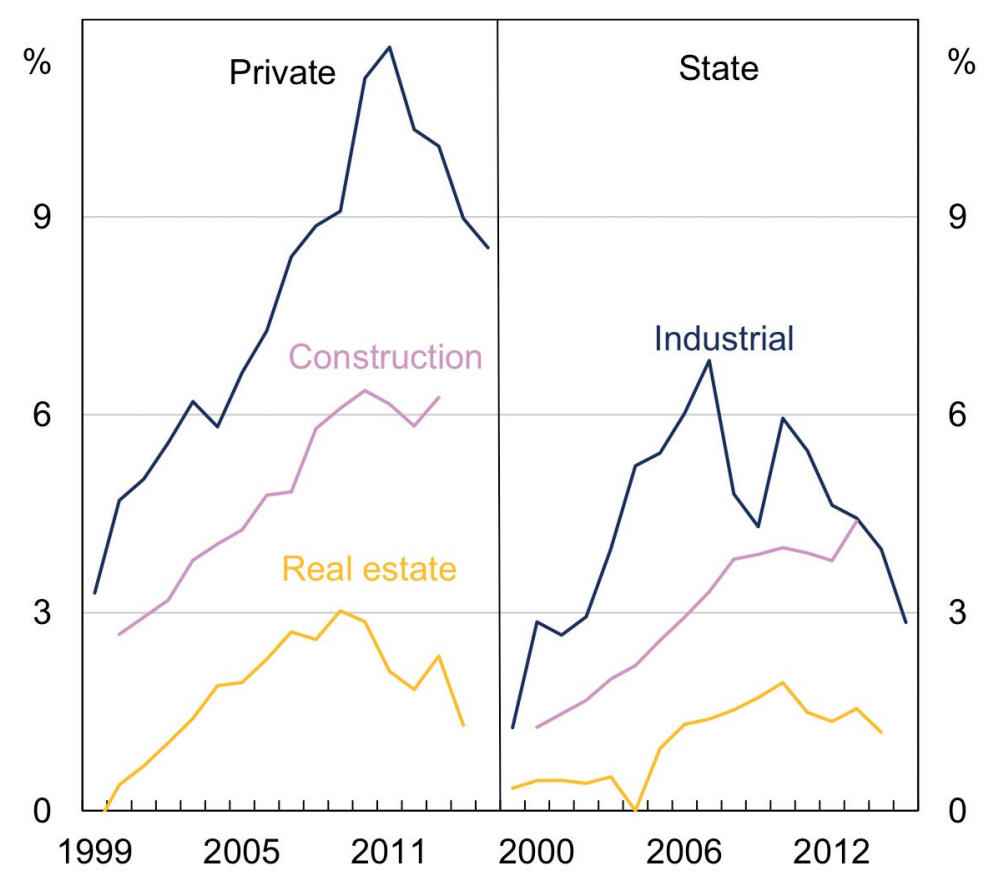

Figure 12.5 China: Return on assets by industry (profit, relative to assets)

Note: Data are available to 2015 for industrial firms, to 2014 for real estate firms and to 2013 for construction firms.

Sources: Authors' calculations; CEIC Data.

\section{Evidence from listed companies}

Official data are drawn from large surveys, but only limited disaggregated information is publicly available. In the absence of firm-level data for the broader corporate sector, listed company data can be consulted to shed light on the financing behaviour of a subset of non-financial companies. We construct our sample of listed firms by combining data from the China Securities Markets and Accounting Research Database (CSMAR) and the Wind Financial Terminal database, encompassing firms' reported balance sheet, cash flow and income statements. Our sample is a panel of more than 2,000 firms listed on the Shanghai and Shenzhen stock exchanges for the years 2000 to 2014, with estimates for 2015 based on data up to the September quarter of that year. As financial firms typically have markedly different capital structures to non-financial companies, we exclude all firms with Global Industry Classification Standard (GICS) classifications corresponding to the banking, diversified financial services, 
capital markets, insurance and consumer finance industries. ${ }^{7}$ We choose a sample beginning in the 2000s to prevent our results being overly affected by reforms impacting on the corporate sector and stock markets in the 1990s and to avoid distortions due to the adoption of new generally accepted accounting principles in the late 1990s. ${ }^{8}$ For reasons discussed in the next section, we use an unbalanced panel of listed companies for our analysis, although separate experiments suggest that the broad findings are not overly sensitive to using a balanced panel of firms.

We classify firms in the sample as state-owned or state-controlled firms ('state firms') based on whether the central State-owned Assets Supervision and Administration Commission, a local government-run asset management bureau, a local government, the Central Government or an SOE is a controlling shareholder. ${ }^{9}$ We remove all observations for firms that have experienced an obvious shift of control from the state towards the private sector or vice versa. It is worth noting, however, that our identification is imperfect as an indicator of state influence on the listed corporate sector. The existence of pyramidal state shareholding schemes (Ding and Su 2008) means that the extent of state control can often be hard to verify. Relatedly, our methodology does not allow us to account for ostensibly 'private' firms whose chief executive officers have close political connections or whose boards are populated by current or former government bureaucrats (see Fan et al. 2007). ${ }^{10}$

7 We prefer the GICS classification to the China Securities Regulatory Commission's 'financial' industry classification, which only includes banks and insurance companies.

8 Qian et al. (2009) note that firms were permitted to issue new shares to raise seasoned equity (as well as rights offerings) from 2001 onwards, but our results are not sensitive to the exclusion of the year 2000 from the sample. A more serious question is whether the internationalisation of accounting standards to ensure convergence with International Financial Reporting Standards in 2006-07 had a significant effect on financial reporting at the firm level. However, the assessment of Ding and Su (2008) is that the impact is likely to have been modest due to a policy decision to allow only gradual introduction of fair value principles under the revised standards.

9 We use information on controlling shareholders provided by Wind Information Co. Ltd. Chinese official guidelines dictate that 'a controlling shareholder is one that controls $30 \%$ or more of the votes or shares, or who can elect half or more of the directors, or who can through any means effectively control the listed company' (Firth et al. 2012: 436).

10 Fan et al. (2007) find that partially privatised firms with politically connected CEOs perform worse than private firms without political connections. 
For various reasons, the firms in our sample may not be representative of the wider corporate sector. The debt of listed firms has, on average, risen over time, but as of the third quarter of 2015 it accounted for only around 7.5 per cent of total social financing, while total liabilities accounted for roughly 17.5 per cent. Moreover, listed firms are likely to have greater access than the broader corporate sector to equity and bond financing channels. Nonetheless, growth in the debt and liabilities of listed firms has tracked growth in broad credit to the real economy (as measured by total social financing) reasonably closely, especially since the late 2000s (Figure 12.6).

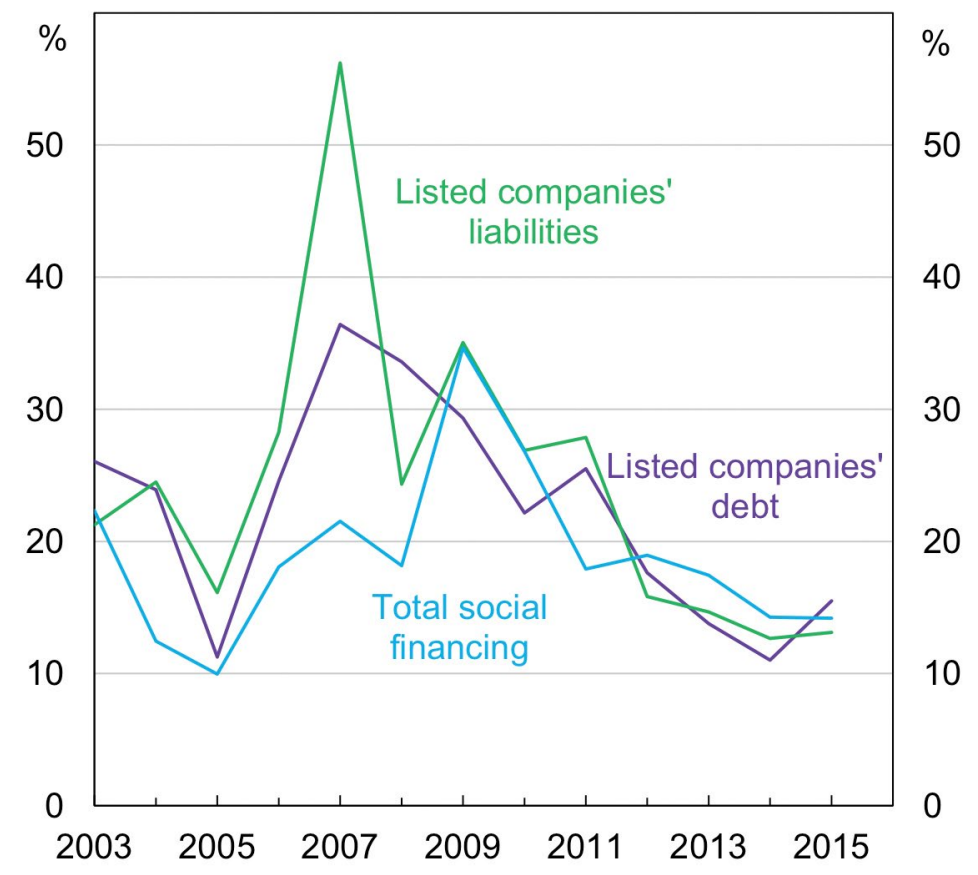

Figure 12.6 China: Annual growth of liabilities and debt

Note: Latest data are estimates based on data up to the September quarter 2015. Listed company data are for non-financial firms only.

Sources: Authors' calculations; CEIC; CSMAR; WIND Information. 
If we consider listed firm liabilities and debt as a share of income (measured by EBIT), the broad pattern observed in the economy-wide debt-to-GDP ratio since the late 2000s can also be observed for these companies (Figure 12.7). ${ }^{11}$ However, the picture for traditional leverage ratios is less straightforward (Figure 12.8). Trends in the ratio of liabilities to assets for listed companies differ by ownership/control. On average (weighted by assets), the leverage of private firms was higher than that of state firms in the early 2000s, but trended lower from 2005 to 2011 before rising again. In contrast, state firms' leverage increased steadily in the early 2000s, accelerated in the last few years of that decade and has been higher than the leverage of private firms in recent years. These trends are more striking when the distribution of leverage across companies is considered. Measures of median leverage and the leverage of the 90th percentile of listed companies indicate that private firms' leverage fell significantly over the past decade to be well below the levels of state-owned or controlled companies.

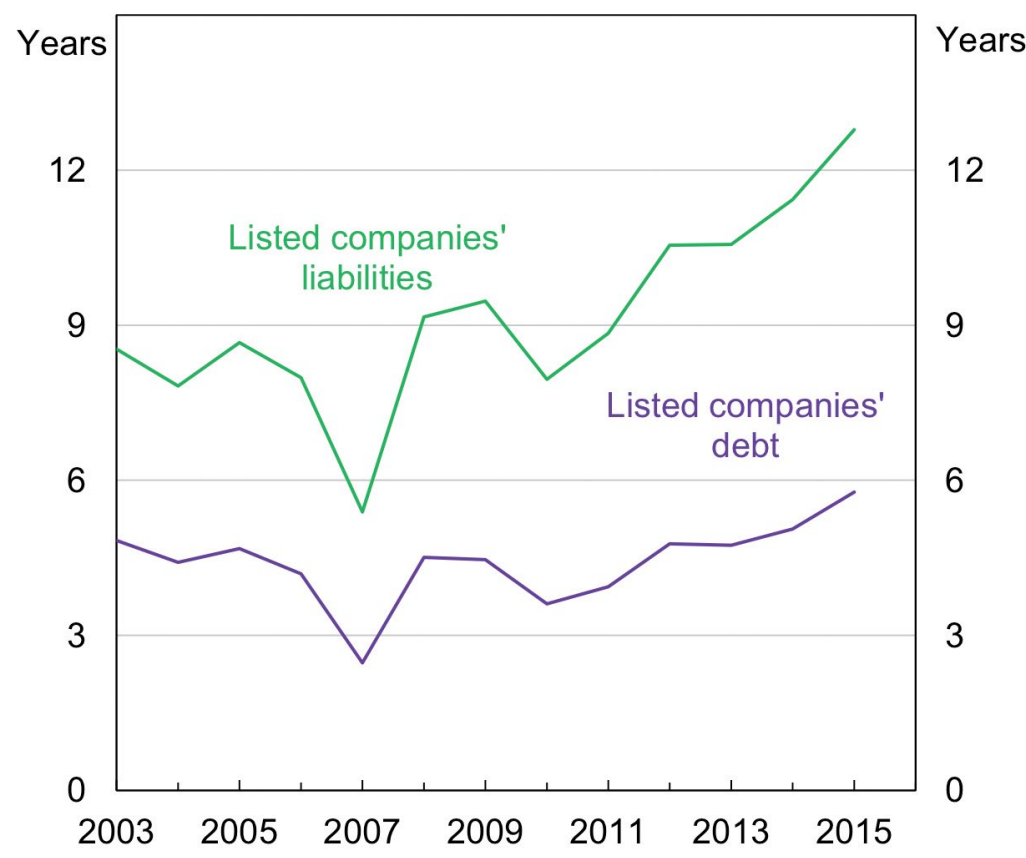

Figure 12.7 China: Liabilities and debt (ratio to EBIT, non-financial listed companies)

Note: Latest data are estimates based on data up to the September quarter 2015.

Sources: Authors' calculations; CSMAR; WIND Information.

11 We use the ratio of liabilities or debt to earnings before interest and tax (EBIT) rather than to earnings before interest, tax, depreciation and amortisation (EBITDA). Financial analysts often prefer to use EBITDA, but as data on depreciation and amortisation are unavailable or incomplete for some companies, we use EBIT instead. 


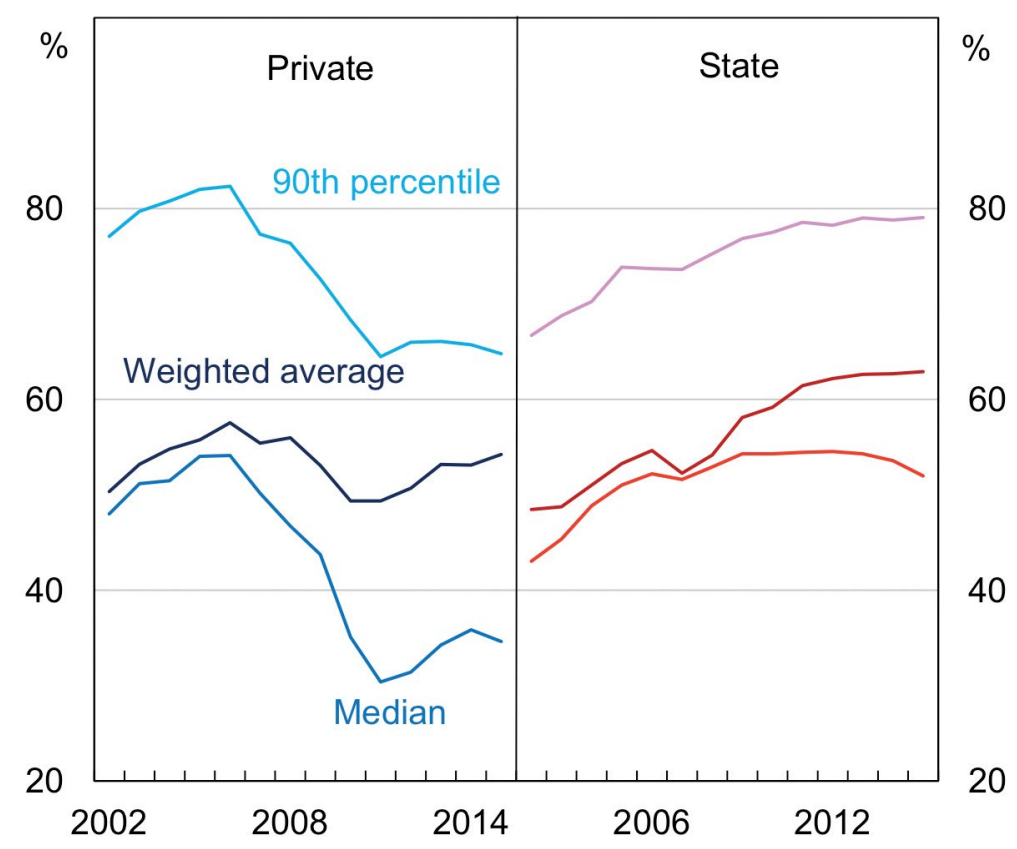

Figure 12.8 China: Liabilities-to-assets ratio of non-financial listed companies

Note: Latest data are estimates based on data up to the September quarter 2015. The weighted average leverage ratio weights each firm's liabilities-to-assets ratio by that firm's share of total listed company assets.

Sources: Authors' calculations; CSMAR; WIND Information.

When the narrower debt-to-assets ratio is used, the divergence in weighted average leverage between the private and the state sectors is less apparent, although somewhat similar patterns can be observed for the median and the 90th percentile measures (Figure 12.9). On average (weighted by assets), private firms' debt-to-assets ratios have declined, but have been only slightly below those of state firms in recent years. At the same time, compared with the liabilities-to-assets ratio, for state firms there is little evidence of an upward trend in the debt-to-assets ratio over the second half of our sample period. The difference reflects the exclusion of non-debt liabilities from the debt-toassets ratio. In particular, accounts payable and advance receipts have both grown more strongly as a share of total liabilities for state companies than they have for private firms (Figure 12.10). 


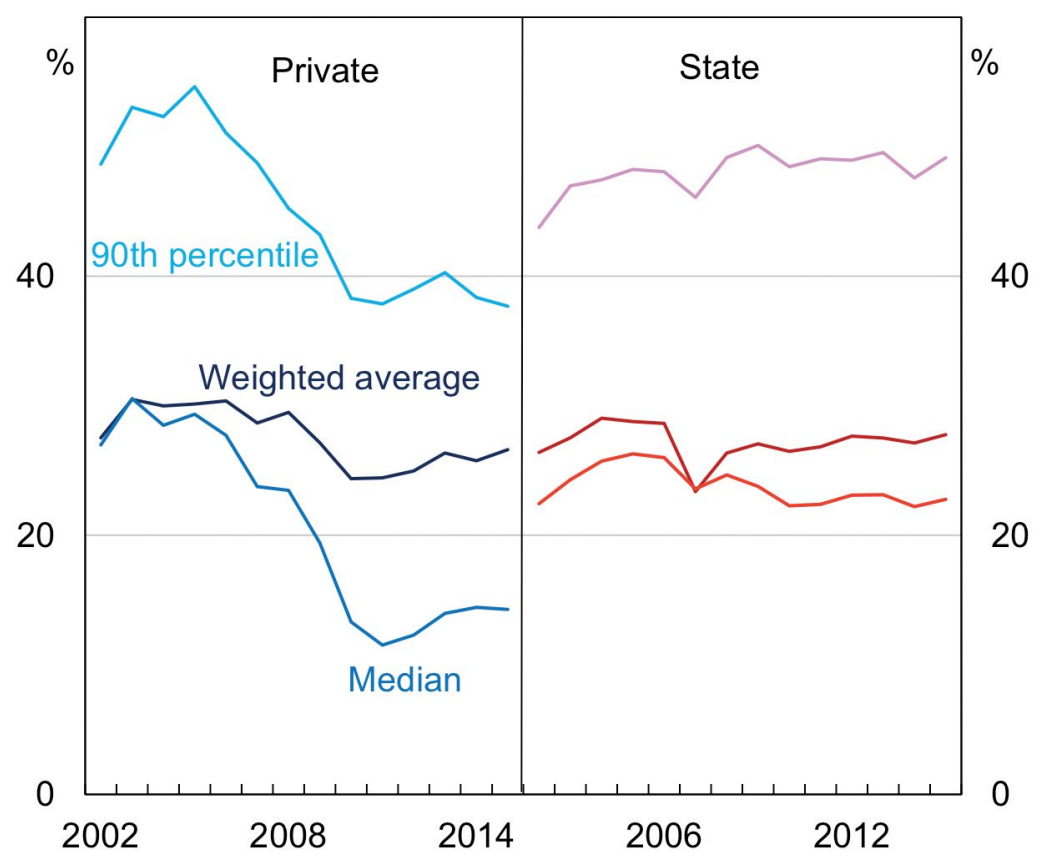

Figure 12.9 China: Debt-to-assets ratio of non-financial listed companies

Note: Latest data are estimates based on data up to the September quarter 2015. The weighted average leverage ratio weights each firm's liabilities-to-assets ratio by that firm's share of total listed company assets.

Sources: Authors' calculations; CSMAR; WIND Information.

Accounts payable can be thought of as an alternative form of short-term credit that allows firms to receive goods or services now and pay for them in the future. Although these are not interest-bearing agreements, they are typically structured so that firms receive discounts from suppliers to pay before a certain date, which can in effect give them the characteristics of debt instruments. The increase in accounts payable relative to other liabilities can be observed in several industries, but is most pronounced for the real estate industry (Figure 12.11). ${ }^{12}$

12 While the ratio to total liabilities has been relatively stable in the past few years for the real estate and construction industries, and has fallen for the mining industry, the median ratio of accounts payable to operating revenue has risen sharply since 2008 for all three industries. This suggests that the capacity to make payments from current sales in these industries has fallen. 


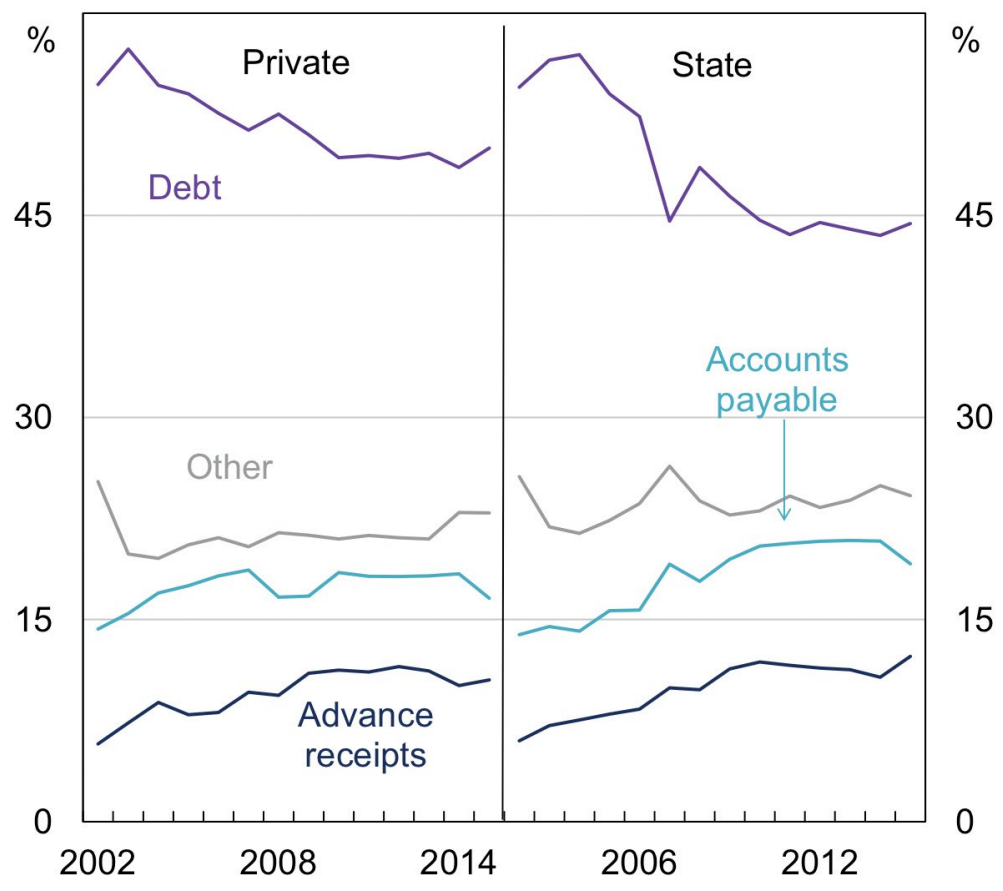

Figure 12.10 China: Composition of liabilities by ownership/control (share of total liabilities)

Note: Latest data are estimates based on data up to the September quarter 2015. All data are for non-financial listed companies.

Sources: Authors' calculations; CSMAR; WIND Information.

Advance receipts are funds received now in exchange for the provision in the future of a good or service, and could also be considered a form of credit. An example of an advance receipt is a real estate developer preselling a property that is yet to be built. This increases liabilities while generating cash. The increase in the share of advance receipts over the past 15 years has been almost entirely attributable to the real estate and construction industries, and real estate has more exclusively driven the increase since the late 2000s (Figure 12.11). It is possible the increased use of both accounts payable and advance receipts in recent years has substituted for debt. Together, they largely explain the divergences that have emerged between the liabilities-to-assets and debt-to-assets ratios. 


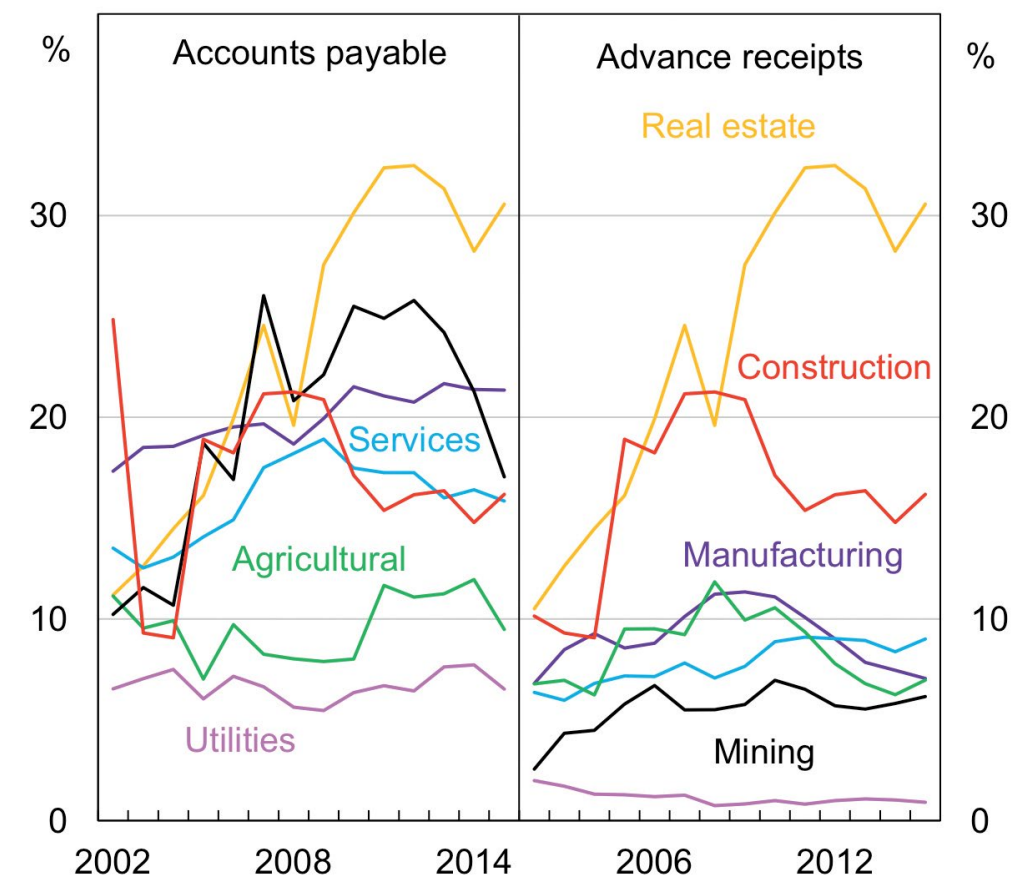

Figure 12.11 China: Composition of liabilities by industry (share of total liabilities)

Note: Latest data are estimates based on data up to the September quarter 2015. All data are for non-financial listed companies.

Sources: Authors' calculations; CSMAR; WIND Information.

It is worth noting that a rise in accounts payable as a share of liabilities can occur for many reasons and does not necessarily indicate a problem. Nonetheless, rapid or persistent increases may signify repayment difficulties for some listed companies. Similarly, for firms such as property developers, a rise in advance receipts relative to other liabilities could (as with an increase in other types of liabilities including debt) signal an increased likelihood of financial stress in the event that current funding is insufficient to meet related contractual obligations.

At the industry level, the liabilities-to-assets ratio has been consistently higher for the real estate, construction and utilities industries over the sample period. Leverage has risen noticeably since 2008 for the real estate, construction and 
mining industries and to a lesser extent for services industries (Figure 12.12). ${ }^{13}$ In contrast, leverage in the manufacturing and utilities industries has eased a little since the late 2000s. ${ }^{14}$

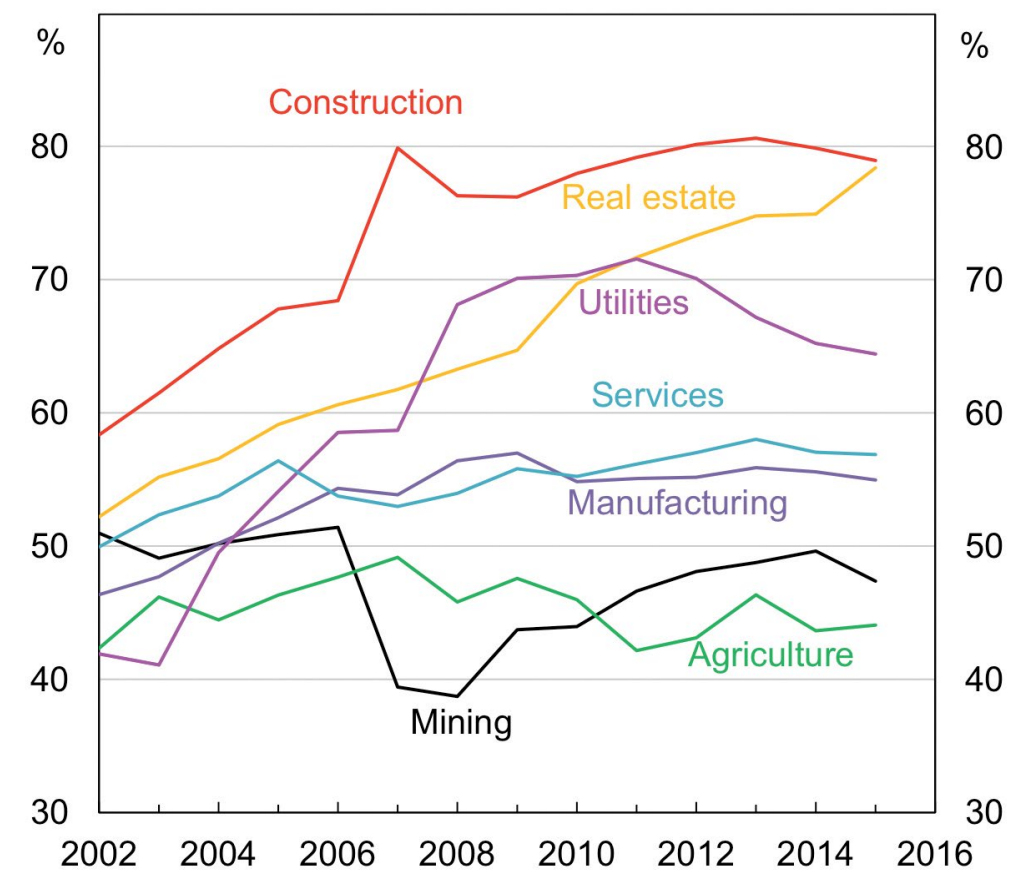

Figure 12.12 China: Leverage of non-financial listed companies by industry (ratio of liabilities to assets)

Note: Latest data are estimates based on data up to the September quarter 2015.

Sources: Authors' calculations; CSMAR; WIND Information.

Apart from debt-to-assets and liabilities-to-assets ratios, other measures of leverage that are commonly used to analyse corporate indebtedness are the debt-to-equity and liabilities-to-equity ratios (Figure 12.13). The ratio of debt to equity has followed a similar trend to the liabilities-to-assets ratio-specifically, it has increased by almost 20 percentage points since 2002. The ratio of liabilities to equity has shown an even sharper increase over the past decade, rising from

13 The measures we present for the services sector include data for the following industries: accommodation and catering; transportation and logistics; wholesale and retail trade; rental and commercial services; culture, sport and recreation; information technology (IT) and software; scientific, research and technical services; health and social work; and education.

14 In general, the trajectory of leverage for each industry is similar whether the debt-to-assets, debt-toequity, liabilities-to-assets or liabilities-to-equity ratios are used. The upward trajectory for real estate and construction industries, relative to other industries, appears more dramatic in the case of the liabilities-toequity ratio than for the liabilities-to-assets ratio. The leverage of the utilities industry appears noticeably higher compared with other industries if the debt-to-assets ratio is considered. 
around 100 per cent in 2002 to nearly 160 per cent in 2015 . The divergent trends reflect the fact that assets have grown at a faster rate than equity while debt has fallen as a share of liabilities, which is not surprising given the accounting identity between assets and the sum of liabilities and equity. As discussed above, the increase in non-debt liabilities is due to an increase in accounts payable (funds owed to other suppliers) and advance receipts (whereby firms have received payment but are yet to provide related goods or services).

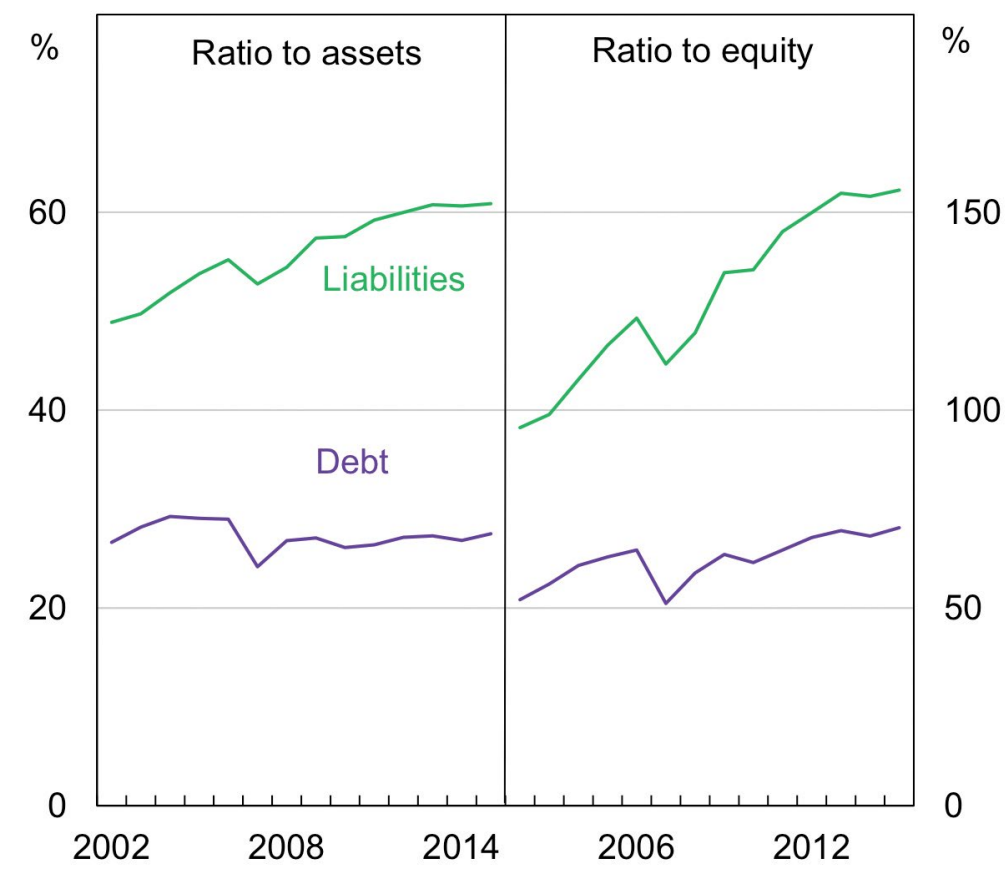

Figure 12.13 China: Measures of non-financial listed company leverage

Note: Latest data are estimates based on data up to the September quarter 2015.

Sources: Authors' calculations; CSMAR; WIND Information.

As is the case with the official industrial survey data, the divergence of leverage patterns between listed private and state companies has been accompanied by a divergence in their operating performance. Prior to 2008, listed state firms were more profitable than private firms and their operating performance, as measured by the ratio of EBIT to assets, was clearly higher (Figure 12.14). In part, this explains the finding of Chen et al. (2009), based on econometric analysis of a similar dataset up to 2004, that private firms' operating performance was inferior to that of both central government and local government-controlled SOEs. More recent data, however, highlight the dramatic reversal that occurred after 2008. Since 2009, private firms have instead experienced a sustained improvement in 
profitability relative to state firms, while the operating performance of the latter has fallen in both relative and absolute terms. This pattern is generally also apparent at the industry level. ${ }^{15}$

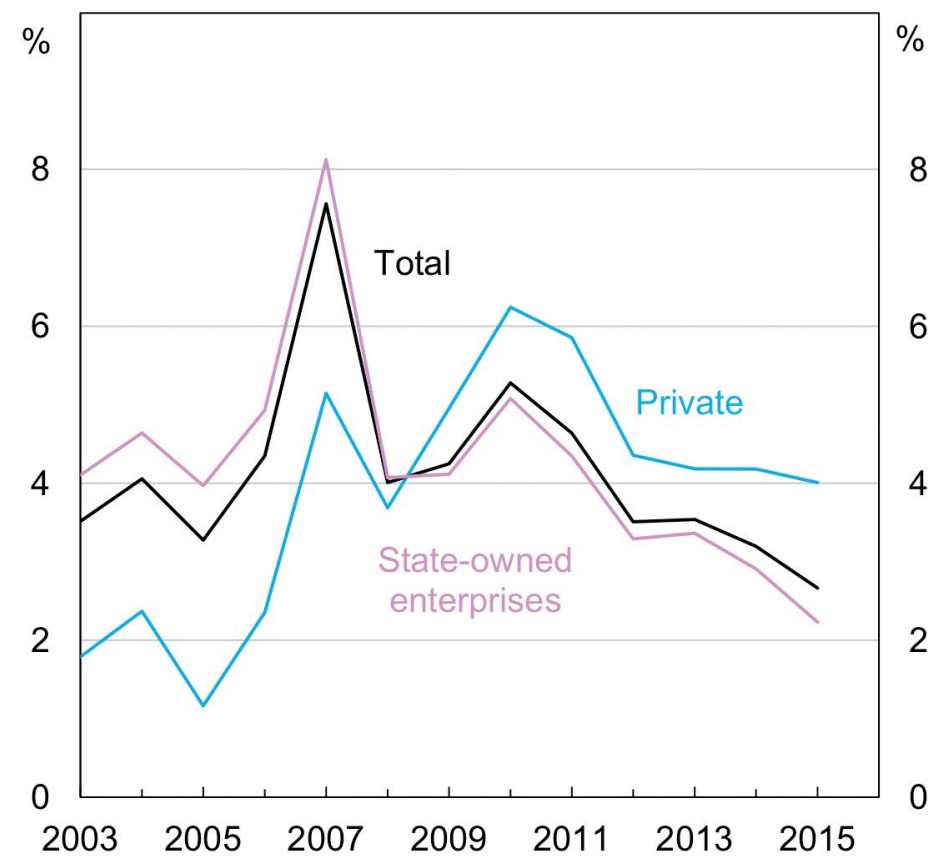

Figure 12.14 China: Return on assets of non-financial listed companies (net profit, ratio to assets, per cent)

Note: Latest data are estimates based on data up to the September quarter 2015.

Sources: Authors' calculations; CSMAR; WIND Information.

In summary, aggregate trends in listed company data indicate that leverage has increased for state firms in absolute terms and also relative to private firms since the stimulus of 2008-09. This was, moreover, accompanied by a simultaneous deterioration in their relative operating performance. However, another feature of our sample is that, while state-owned or controlled companies (based on our definitions) constitute the bulk - about three-quarters - of non-financial listed company assets, private firms appear to have accounted for a rising share of assets since the late 2000s. ${ }^{16}$ The relative increase in private sector assets has

15 An exception is the utilities industry, in which the operating performance of state firms has improved relative to private firms in recent years.

16 These estimates differ from Chivakul and Lam (2015), who find that around two-thirds of the assets of listed firms are under state ownership or control, although they also find that the state share has fallen in recent years. 
been broad-based across most major asset types. ${ }^{17}$ As the next section shows, a consequence of this compositional shift is that the private sector has been responsible for a larger proportion of the change in listed company leverage than average leverage ratios for state and private firms would suggest.

\section{Decomposing listed company leverage}

To clarify the sources and composition of rising listed company leverage since the late 2000s, we use a simple arithmetic decomposition to calculate contributions to leverage by firm ownership/control and by industry. To do this, we exploit the following identity (Equation 12.1).

\section{Equation 12.1}

$$
L_{t}=\frac{\sum_{i} l_{i t}}{\sum_{i} a_{i t}}=\sum_{i} \frac{l_{i t}}{a_{i t}} \cdot \frac{a_{i t}}{\sum_{i} a_{i t}}
$$

In Equation 12.1, $L_{t}$ is the total liabilities-to-assets ratio for our sample at time $t ; l_{i t}$ corresponds to the liabilities of a subset of firms, $i$, at time $t$; and $a_{i t}$ corresponds to the assets of the same subset, $i$, at time $t$ (for example, $i$ could refer to different industries or firm ownership types).

We focus on the liabilities-to-assets ratio because narrower measures, such as the debt-to-assets ratio, exclude the striking rise in non-debt liabilities since the early 2000s. Although it is more common in the corporate finance literature to use the debt-to-assets ratio, broader leverage ratios have been used in several recent studies of Chinese corporate behaviour (Li et al. 2009; Yu 2013; Chivakul and Lam 2015). ${ }^{18}$

Tables 12.1 and 12.2 consider how the liabilities-to-assets ratio has been affected by compositional change in ownership or control of listed companies, and the relative importance of old and new firms in driving leverage. Table 12.1 shows leverage ratios calculated for state and private firms. For both state and private firms, we show the leverage ratios for a 'matched sample' of firms that were continuously listed between 2008 and 2015 and the remaining firms, which were listed for part of that same period (net new entrants to the sample). For firms that were listed for the period 2008-15, we also consider the leverage of firms

17 Growth since 2008 has been faster for private than for state firms in the case of cash, net accounts receivable, net prepayments, net inventories, equity, net fixed assets and net intangible assets. Growth in net long-term equity investment has been faster for state firms.

18 Recent history also suggests that non-debt liabilities have been an important aspect of leverage in China. A feature of the macrofinancial challenges faced by Chinese authorities in the late 1990s was a rise in interenterprise liabilities (often described as 'triangular debt'), which typically took the form of unpaid bills owing from state-owned to private firms (Lardy 1998: 40-41). 
that already displayed 'high' leverage in 2008 and of those firms whose leverage was lower. For the latter comparison, we define 'high' leverage as a liabilitiesto-assets ratio of 0.75 (75 per cent). This compares with a median leverage ratio of a little less than 0.5 in our sample. Having calculated these leverage ratios, Table 12.2 multiplies each by their weight (the proportional share of assets due to each category) to compute contributions of each category to aggregate leverage for the listed company sample. ${ }^{19}$

Table 12.1 Leverage by firm ownership/control

\begin{tabular}{|l|r|r|r|r|}
\hline & \multicolumn{3}{|c|}{$\begin{array}{r}\text { Liabilities-to-assets ratio } \\
\text { (per cent) }\end{array}$} & $\begin{array}{c}\text { Average annual change } \\
\text { (percentage points) }\end{array}$ \\
\cline { 2 - 5 } & 2008 & 2012 & 2015 & $\mathbf{2 0 0 8 - 1 5}$ \\
\hline State-owned or controlled & 54.2 & 62.2 & 62.9 & 1.2 \\
\hline Matched sample (2008-15) & 54.2 & 61.2 & 61.8 & 1.1 \\
\hline Leverage > 0.75 in 2008 & 82.5 & 79.6 & 77.3 & -0.7 \\
\hline Leverage $\leq$ 0.75 in 2008 & 48.4 & 57.2 & 58.4 & 1.4 \\
\hline Net new entry (2008-15)(a) & 70.0 & 69.2 & 69.4 & -0.1 \\
\hline Private & 56.0 & 50.7 & 54.2 & -0.3 \\
\hline Matched sample (2008-15) & 56.0 & 58.3 & 60.7 & 0.7 \\
\hline Leverage > 0.75 in 2008 & 88.6 & 70.8 & 69.5 & -2.7 \\
\hline Leverage $\leq 0.75$ in 2008 & 52.3 & 56.9 & 59.7 & 1.1 \\
\hline Net new entry (2008-15)(a) & 24.6 & 36.5 & 45.5 & 3.5 \\
\hline
\end{tabular}

(a) For comparison with later leverage ratios and consistency with the annual average change calculation, the leverage ratio for 2009 is given in the first column.

Sources: Authors' calculations; CSMAR; WIND Information.

The decomposition shows that state-owned or controlled firms accounted for the majority of listed company leverage in the period after 2008. The bulk of this leverage was due to firms that were already listed in 2008, although firms listed since 2008 (or delisted) have accounted for an increasing share. Overall, the leverage of state firms increased steadily over this period, while the leverage of private firms declined for a time before picking up again after 2011 (Table 12.1). However, the value of assets in private hands increased relative to the value of state sector assets. This is what accounts for the modest fall in the state sector's share of leverage since 2008 (Table 12.2).

19 We do not exclude outliers from the sample when performing this exercise, as we do for the econometric exercises in the next section. Applying outlier correction strategies, such as censoring leverage on the unit interval or excluding firms whose leverage exceeds a certain threshold, makes a modest quantitative difference and virtually no qualitative difference to the results. 
Table 12.2 Compositional change in leverage by firm ownership/control

\begin{tabular}{|c|c|c|c|c|}
\hline & \multicolumn{3}{|c|}{$\begin{array}{l}\text { Share of total liabilities-to-assets } \\
\text { ratio (per cent) }\end{array}$} & \multirow{2}{*}{\begin{tabular}{r}
\multicolumn{1}{c}{$\begin{array}{c}\text { Change } \\
\text { (percentage points) }\end{array}$} \\
$2008-15$
\end{tabular}} \\
\hline & 2008 & 2012 & 2015 & \\
\hline State-owned or controlled & 84.7 & 83.8 & 79.2 & -5.6 \\
\hline Matched sample (2008-15) & 84.7 & 72.0 & 66.1 & -18.6 \\
\hline Leverage > 0.75 in 2008 & 22.0 & 16.4 & 14.9 & -7.1 \\
\hline Leverage $\leq 0.75$ in 2008 & 62.8 & 55.5 & 51.2 & -11.6 \\
\hline Net new entry (2008-15) & 0.0 & 11.8 & 13.0 & 13.0 \\
\hline Private & 15.3 & 16.2 & 20.8 & 5.6 \\
\hline Matched sample (2008-15) & 15.3 & 12.1 & 13.4 & -1.8 \\
\hline Leverage $>0.75$ in 2008 & 2.4 & 1.5 & 1.6 & $-0 . \varsigma$ \\
\hline Leverage $\leq 0.75$ in 2008 & 12.8 & 10.7 & 11.9 & -0.5 \\
\hline Net new entry (2008-15) & 0.0 & 4.1 & 7.4 & 7.4 \\
\hline
\end{tabular}

Sources: Authors' calculations; CSMAR; WIND Information.

The data suggest that, on average, firms with leverage ratios exceeding 0.75 in 2008 deleveraged over the subsequent seven years (most prominently in the case of private firms). This parallels the finding that the leverage of the ninetieth percentile of the listed company distribution declined after 2008 for private companies and was relatively stable for state firms (see section two). In contrast, there is evidence that firms with lower leverage than this in 2008 'leveraged up', on average, although the weight of these firms in the sample (the proportional value of their assets) fell by a greater amount, resulting in a declining contribution to overall leverage.$^{20}$ The leverage of net new entrants to the sample of state firms was relatively stable over the 2009-15 period, but the weight of these firms in the sample increased sharply, leading them to account for a rising share of total listed company leverage. Net new private entrants, in contrast, saw rapid average annual growth in leverage. When combined with their rising weight in the sample, this also resulted in them accounting for an increasing share of overall leverage.

20 An analysis of the incidence of firms with leverage within certain ranges delivers slightly different findings, as it does not take into account the weight of each firm in terms of its share of total assets in the listed company sample. Since 2008, the majority of firms (between 86 and 90 per cent) have had leverage ratios equal to or less than 0.75 . The proportion of these firms in the sample declined between 2008 and 2013 and has subsequently increased. Within this group, the share of firms in the $0.25-0.5$ range fell and the share in the $0.5-0.75$ range rose between 2008 and 2013 - a trend that reversed after 2013. The proportion of firms with leverage above 0.75 has fallen since 2013. 
While Table 12.2 summarises the contributions of different types of firms to the overall level of leverage, a similar decomposition can also be used to consider contributions to the change in leverage (Equation 12.2).

\section{Equation 12.2}

$$
\Delta L_{t}=\sum_{i}\left(\frac{l_{i t}}{a_{i t}} \cdot \frac{a_{i t}}{\sum_{i} a_{i t}}-\frac{l_{i t-1}}{a_{i t-1}} \cdot \frac{a_{i t-1}}{\sum_{i} a_{i t-1}}\right)
$$

Looking at contributions of each type of firm to the overall leverage, it is apparent that state firms accounted for the bulk of the increase in leverage between 2008 and 2012, but subsequently subtracted from growth in leverage (Table 12.3). The further increase in leverage since 2012 can thus be attributed mainly to private firms. Deleveraging by highly leveraged firms (especially state firms) subtracted significantly from the rise in leverage over the 2008-15 period. In net terms, new entrants to the sample contributed strongly to growth in leverage. New listed state firms accounted for most of the increase between 2008 and 2012, but new private firms accounted for the bulk of the increase in leverage thereafter.

Table 12.3 Contributions to the change in leverage by firm ownership/control

\begin{tabular}{|l|r|r|r|}
\hline & \multicolumn{2}{|c|}{$\begin{array}{c}\text { Contribution to change in } \\
\text { total liabilities-to-assets } \\
\text { ratio (percentage points) }\end{array}$} & $\begin{array}{c}\text { Cumulative } \\
\text { (percentage points) }\end{array}$ \\
\cline { 2 - 4 } & $2008-12$ & $2012-15$ & $2012-15$ \\
\hline Total & 5.5 & 0.9 & 6.4 \\
\hline State-owned or controlled & 4.1 & -2.1 & 2.1 \\
\hline Matched sample (2008-15) & -3.0 & -2.9 & -5.9 \\
\hline Leverage $>0.75$ in 2008 & -2.1 & -0.8 & -2.9 \\
\hline Leverage $\leq 0.75$ in 2008 & -0.9 & -2.1 & -3.0 \\
\hline Net new entry (2008-15) & 7.1 & 0.9 & 7.9 \\
\hline Private & 1.4 & 3.0 & 4.4 \\
\hline Matched sample (2008-15) & -1.0 & -0.5 & -0.1 \\
\hline Leverage $>0.75$ in 2008 & -0.6 & 0.1 & -0.4 \\
\hline Leverage $\leq 0.75$ in 2008 & 2.4 & 0.8 & 0.3 \\
\hline Net new entry (2008-15) & 2.1 & 4.5 \\
\hline
\end{tabular}

Sources: Authors' calculations; CSMAR; WIND Information. 
In summary, although the leverage of state firms increased and the leverage of private firms fell overall, the more highly leveraged private and state firms deleveraged (most prominently in the case of private firms). Virtually all other categories of firms experienced an increase in leverage, and the rising weight of private firms in the sample resulted in them accounting for an increasing share of total leverage. Indeed, private firms have accounted for much of the increase in leverage since 2008 and particularly over the past few years.

Table 12.4 Leverage by industry

\begin{tabular}{|c|c|c|c|c|}
\hline & \multicolumn{3}{|c|}{ Liabilities-to-assets ratio } & \multirow{2}{*}{$\begin{array}{r}\begin{array}{c}\text { Average annual change } \\
\text { (percentage points) }\end{array} \\
2008-15\end{array}$} \\
\hline & 2008 & 2012 & 2015 & \\
\hline Real estate & 63.3 & 73.3 & 78.4 & 2.2 \\
\hline State-owned or controlled & 63.4 & 73.2 & 78.5 & 2.2 \\
\hline Private & 62.9 & 73.6 & 78.0 & 2.1 \\
\hline Construction & 76.3 & 80.1 & 78.9 & 0.4 \\
\hline State-owned or controlled & 76.5 & 80.9 & 79.8 & 0.5 \\
\hline Private & 72.8 & 63.4 & 64.6 & -1.2 \\
\hline Manufacturing & 56.4 & 55.2 & 55.1 & -0.2 \\
\hline State-owned or controlled & 57.7 & 60.5 & 60.4 & 0.4 \\
\hline Private & 52.0 & 45.2 & 46.9 & -0.7 \\
\hline Utilities & 68.1 & 70.1 & 64.4 & -0.5 \\
\hline State-owned or controlled & 68.4 & 70.5 & 64.7 & -0.5 \\
\hline Private & 60.8 & 57.4 & 56.8 & -0.6 \\
\hline Mining & 38.7 & 48.1 & 47.4 & 1.2 \\
\hline State-owned or controlled & 38.6 & 48.1 & 47.3 & 1.2 \\
\hline Private & 50.6 & 45.0 & 50.0 & -0.1 \\
\hline Services & 53.7 & 57.0 & 57.0 & 0.5 \\
\hline State-owned or controlled & 53.6 & 57.7 & 57.2 & 0.5 \\
\hline Private & 54.2 & 53.9 & 56.4 & 0.3 \\
\hline Other & 51.2 & 56.9 & 59.1 & 1.1 \\
\hline State-owned or controlled & 45.9 & 61.8 & 62.7 & 2.4 \\
\hline Private & 59.4 & 44.5 & 52.7 & -1.0 \\
\hline
\end{tabular}

Sources: Authors' calculations; CSMAR; WIND Information. 
At the industry level, the increase in leverage since 2008 has been concentrated in the real estate, construction, mining and services industries (Table 12.4). Over this period, firms in the real estate and construction industries have had persistently higher leverage than firms in other industries. The observed increases in leverage have been more pronounced for state firms than for private companies. Modest deleveraging has been apparent for the manufacturing and utilities sectors, partly offsetting the above trends. Yet the rapid growth of assets in real estate and construction has noticeably boosted the share of the total liabilities-to-assets ratio accounted for by these two industries (Table 12.5).

Table 12.5 Compositional change in leverage by industry

\begin{tabular}{|c|c|c|c|c|}
\hline & \multicolumn{3}{|c|}{$\begin{array}{l}\text { Share of total liabilities-to-assets } \\
\text { ratio (per cent) }\end{array}$} & \multirow{2}{*}{$\begin{array}{c}\begin{array}{c}\text { Change } \\
\text { (percentage points) }\end{array} \\
2008-15\end{array}$} \\
\hline & 2008 & 2012 & 2015 & \\
\hline Real estate & 7.4 & 9.6 & 13.9 & 6.5 \\
\hline State-owned or controlled & 5.5 & 6.9 & 9.8 & 4.4 \\
\hline Private & 2.0 & 2.7 & 4.1 & 2.1 \\
\hline Construction & 8.0 & 16.7 & 16.9 & 8.8 \\
\hline State-owned or controlled & 7.6 & 16.1 & 16.1 & 8.4 \\
\hline Private & 0.4 & 0.6 & 0.8 & 0.4 \\
\hline Manufacturing & 35.6 & 32.5 & 32.0 & -3.6 \\
\hline State-owned or controlled & 28.0 & 23.4 & 21.3 & -6.7 \\
\hline Private & 7.6 & 9.1 & 10.7 & 3.1 \\
\hline Utilities & 10.9 & 8.9 & 7.9 & -3.0 \\
\hline State-owned or controlled & 10.6 & 8.6 & 7.6 & -2.9 \\
\hline Private & 0.3 & 0.2 & 0.2 & -0.1 \\
\hline Mining & 17.1 & 15.3 & 12.3 & -4.8 \\
\hline State-owned or controlled & 17.0 & 15.1 & 12.0 & -5.0 \\
\hline Private & 0.1 & 0.2 & 0.3 & 0.2 \\
\hline Services & 15.8 & 13.2 & 12.6 & -3.2 \\
\hline State-owned or controlled & 14.2 & 11.0 & 9.5 & -4.7 \\
\hline Private & 1.6 & 2.2 & 3.1 & 1.6 \\
\hline Other & 5.1 & 3.8 & 4.4 & -0.7 \\
\hline State-owned or controlled & 1.8 & 2.7 & 2.8 & 0.9 \\
\hline Private & 3.3 & 1.1 & 1.6 & -1.7 \\
\hline
\end{tabular}

Sources: Authors' calculations; CSMAR; WIND Information. 
Table 12.6 Contributions to the change in leverage by industry

\begin{tabular}{|c|c|c|c|}
\hline & \multicolumn{2}{|c|}{$\begin{array}{l}\text { Contribution to change in total liabilities- } \\
\text { to-assets ratio (percentage points) }\end{array}$} & \multirow{2}{*}{$\begin{array}{r}\begin{array}{c}\text { Cumulative } \\
\text { (percentage points) }\end{array} \\
2008-15 \\
\end{array}$} \\
\hline & 2008-12 & 2012-15 & \\
\hline Total & 5.5 & 0.9 & 6.4 \\
\hline Real estate & 1.7 & 2.7 & 4.4 \\
\hline State-owned or controlled & 1.2 & 1.8 & 3.0 \\
\hline Private & 0.6 & 0.9 & 1.4 \\
\hline Construction & 5.6 & 0.3 & 5.9 \\
\hline State-owned or controlled & 5.5 & 0.2 & 5.6 \\
\hline Private & 0.2 & 0.1 & 0.3 \\
\hline Manufacturing & 0.1 & 0.0 & 0.1 \\
\hline State-owned or controlled & -1.2 & -1.0 & -2.3 \\
\hline Private & 1.3 & 1.1 & 2.4 \\
\hline Utilities & -0.6 & -0.5 & -1.2 \\
\hline State-owned or controlled & -0.6 & -0.5 & -1.1 \\
\hline Private & -0.1 & 0.0 & 0.0 \\
\hline Mining & -0.2 & -1.7 & -1.8 \\
\hline State-owned or controlled & -0.2 & -1.7 & -1.9 \\
\hline Private & 0.0 & 0.1 & 0.1 \\
\hline Services & -0.7 & -0.3 & -0.9 \\
\hline State-owned or controlled & -1.1 & -0.8 & -2.0 \\
\hline Private & 0.5 & 0.6 & 1.0 \\
\hline Other & -0.5 & 0.4 & -0.1 \\
\hline State-owned or controlled & 0.6 & 0.1 & 0.7 \\
\hline Private & -1.1 & 0.3 & -0.8 \\
\hline
\end{tabular}

Sources: Authors' calculations; CSMAR; WIND Information.

If we decompose the change in leverage, a similar picture is revealed (Table 12.6). State-owned or controlled real estate and construction firms have accounted for the bulk of the increase in leverage, although private firms in these industries also contributed. All other major industry categories with the exception of manufacturing have subtracted from the increase since 2008. Outside the real estate and construction industries, private firms have tended to make a positive contribution to the change in leverage, particularly in manufacturing and services industries, while state firms have generally made a negative contribution. 
The decomposition of listed company leverage helps identify the broad categories of firms that have underpinned rising leverage since the late 2000s. It shows that certain industries (especially real estate and construction) have been important drivers of the pick-up in leverage and that firms in these industries have typically been more highly leveraged than other firms. Second, it indicates that state firms were the key drivers of this increase in the immediate aftermath of the 2008-09 stimulus, but also that private firms have made a larger contribution to the rise in leverage in the past few years. While the decomposition does not shed light on the drivers of leverage at the firm level, it suggests that the industry to which a firm belongs and its ownership/control are likely to be important. To consider these issues in more depth, in the next section we model the capital structure decisions of listed firms using a similar dataset.

\section{Modelling Chinese-listed company leverage}

In the corporate finance literature, two main hypotheses have typically been considered in the analysis of firms' capital structure choices. The trade-off theory holds that optimal leverage is attained when the marginal tax benefit of higher leverage equals the marginal potential cost of financial distress. The theory predicts that firms will therefore set a target debt-to-value ratio. Assuming that there are costs of adjustment, they will move towards this target gradually (Flannery and Rangan 2006). In contrast, the pecking order theory predicts that, in an environment of asymmetric information between owners and managers, firms will prefer internal to external funds and debt to equity if external financing is required (Donaldson 1961; Myers 1984). ${ }^{21}$

In the case of China, Chen's (2004) panel study of Chinese-listed firms fails to find evidence for either hypothesis, but characterises capital structure decisions as following a 'modified pecking order' rule. More recent work, by Huang and Song (2006) and Qian et al. (2009), has tended to find more support for the tradeoff theory. Qian et al. (2009) present evidence that a firm's current leverage ratio is strongly correlated with that in the previous period, which is consistent with sluggish adjustment to some 'target' leverage ratio.

21 Firms prefer debt to equity because the agency cost is higher for equity. The market may misprice equity if new investors are less well informed than current shareholders with access to private information. Underpricing by the market allows new investors to capture more of the net present value (NPV) of the project than current shareholders, leading to the project being rejected even if the NPV is positive (Harris and Raviv 1991). 


\section{Models and data}

We consider both static and dynamic panel approaches to modelling the leverage of listed firms, using annual firm-level data for nearly 2,500 firms from 2000 to 2015. The basic static, fixed-effects model of leverage is specified as Equation 12.3 .

\section{Equation 12.3}

$$
L_{i t}=\alpha+X_{i t} \beta+Z_{t} \gamma+\mu_{i}+\eta_{i t}
$$

In Equation 12.3, $L_{i t}$ is the leverage ratio of firm $i$ in year $t, X_{i t}$ is a vector of time-varying, firm-level explanatory variables and $Z_{t}$ is a vector of additional determinants of leverage that vary over time but are the same for all firms. In our model, this vector consists of several time dummy variables. The firm fixed effect is given by $\mu_{i^{\prime}}$ and $\eta_{i t}$ is the error term.

Static models may be incorrectly specified if firms' capital structure choices reflect their past borrowing behaviour as well as their current external finance needs. Flannery and Rangan (2006) argue that firms in the United States target a long-run leverage ratio (which itself might depend on pecking order or other considerations) and that a firm will converge to its long-run target gradually. This can be modelled as Equation 12.4.

\section{Equation 12.4}

$$
L_{i t}-L_{i t-1}=\lambda\left(L_{i t}^{*}-L_{i t-1}\right)=\lambda\left(\delta+X_{i t} \tau+Z_{t} \theta+\varphi_{i}+\omega_{i t}\right)-\lambda L_{i t-1}
$$

In Equation 12.4, target leverage, $L_{i t}^{*}$, depends on the same standard static determinants of leverage included in Equation 12.3, and where $0<\lambda<1$ is the speed of adjustment. Adding lagged leverage to both sides yields Equation 12.5.

\section{Equation 12.5}

$$
L_{i t}=v+(1-\lambda) L_{i t-1}+\boldsymbol{X}_{i t} \phi+Z_{t} \psi+\xi_{i}+v_{i t}
$$

In Equation 12.5, $\phi=\lambda \tau$ and $\psi=\lambda \theta$. A standard fixed-effects model can be used to estimate $\lambda$. However, it is poorly equipped to model the dynamics of adjustment to the target leverage, because the lagged dependent variable will be correlated with the firm fixed effects and therefore estimated coefficients will be biased (Nickell 1981). As a result, many recent studies, including Qian et al. (2009), have used dynamic panel specifications, estimated using the difference generalised method of moments (GMM) estimator (Holtz-Eakin et al. 1988; 
Arellano and Bond 1991). This approach transforms Equation 12.5 by taking first differences and thereby removing the unobserved firm fixed effects (Equation 12.6).

\section{Equation 12.6}

$$
\Delta L_{i t}=(1-\lambda) \Delta L_{i t-1}+\Delta X_{i t} \phi+\Delta Z_{t} \psi+u_{i t}
$$

To address the endogeneity of lagged dependent variables with respect to the fixed effects, the difference GMM estimator uses lagged levels of the dependent and explanatory variables as instruments. Including lagged levels of explanatory variables in the instrument set allows for the possibility that some regressors are endogenous. This is appealing in the context of corporate finance, as many balance sheet variables are likely to be codetermined rather than exogenous.

However, Blundell and Bond (1998) find that the difference GMM estimator has poor finite sample properties when the lagged levels of the series are only weakly correlated with subsequent first differences, as is often the case with persistent autoregressive processes. They make an assumption that first differences of the instruments are uncorrelated with the fixed effects, and this increases the number of possible instruments. Their system GMM estimator involves a system of two equations, using lagged differences as instruments for the original levels equation and lagged levels as instruments for the difference equation. ${ }^{22}$ Flannery and Hankins (2013) show that this alternative estimator performs better than difference GMM in a range of circumstances for leverage regressions, using simulated US-listed company data. As the system GMM estimator may be preferable to the difference GMM estimator, and neither method is necessarily superior to the other, in this chapter we consider the results of both approaches and compare them with the results of the fixed-effects regression to make an assessment of the drivers of leverage decisions at the firm level.

The leverage measure we employ for our regressions is the liabilities-to-assets ratio. The covariate regressors $\left(\boldsymbol{X}_{i t}\right)$ we use in our estimation are profitability, the market-to-book ratio, collateral, the non-debt tax shield, firm size and industry median leverage. The variables we consider are similar to those used in most previous studies (Table 12.7).

22 A controversial assumption regarding initial conditions, which allows the additional moment conditions to be exploited, is that the difference of the lagged dependent variable in the first period is uncorrelated with the error in the subsequent period. 
Table 12.7 Data summary

\begin{tabular}{|l|r|r|r|r|}
\hline Series & Number & Mean & Median & Standard deviation \\
\hline Leverage & 26,235 & 0.46 & 0.46 & 0.25 \\
\hline Profitability & 24,945 & 0.05 & 0.05 & 0.15 \\
\hline Market-to-book & 21,351 & 2.44 & 1.93 & 1.92 \\
\hline Collateral & 26,235 & 0.26 & 0.22 & 0.18 \\
\hline Non-debt tax shield & 25,602 & 0.02 & 0.02 & 0.02 \\
\hline Size & 26,235 & 21.66 & 21.49 & 1.29 \\
\hline
\end{tabular}

(a) Leverage refers to the book liabilities-to-assets ratio; profitability refers to EBIT divided by total assets; the market-to-book ratio refers to book liabilities plus the market value of equity divided by the book value of total assets; collateral refers to the ratio of fixed assets to total assets; non-debt tax shield refers to depreciation divided by total assets; and size refers to the natural logarithm of total assets (denominated in local currency).

Sources: Authors' calculations; CSMAR; WIND Information.

Profitability is measured as EBIT divided by total assets. ${ }^{23}$ The pecking order theory predicts that firms will prefer to finance projects with retained earnings rather than debt, and hence implies a negative relationship with profitability (Myers and Majluf 1984). More profitable firms may also use their profits to pay down debt. An alternative view is that creditors will be more willing to lend to firms with stronger cash flows, as higher earnings imply greater capacity to meet debt payments. However, the aggregate comparisons in section two suggest a negative correlation between leverage and profitability.

The market-to-book ratio of assets (or price-to-book ratio) is commonly used in the literature as a proxy for growth opportunities. This ratio may be associated with either higher leverage (due to greater demand for external funds to realise these opportunities) or lower leverage (if these earning opportunities reduce the need for or incentive to take on additional debt).

To proxy firms' overall debt-raising capacity and available collateral, in the form of tangible assets, we use the ratio of fixed assets to total assets.

As a proxy for the non-debt tax shield, we use depreciation expense divided by total assets. The non-debt tax shield reduces the incentive for firms to prefer debt financing as a means of obtaining interest reductions when filing tax returns. 
The log of the book value of total assets measures firm size. Larger firms may be lower-risk debtors, with reduced probability of bankruptcy, leading them to take on higher leverage. An alternative (pecking order) view is that older and larger firms may have had greater opportunities to retain earnings. ${ }^{24}$

We use median industry leverage as an additional variable in our analysis, to control for capital structure characteristics at the industry level. Frank and Goyal (2009) argue that this variable may act as a proxy for several determinants of leverage, including regulatory factors. ${ }^{25}$ The decomposition in section three highlights the significance of real estate and construction industries in driving aggregate leverage patterns, which suggests a role for industry-level leverage in influencing leverage decisions at the firm level.

An implication of the analysis in the previous two sections is that state or private ownership/control has been an important factor in driving leverage outcomes. This is especially the case in the aftermath of the large fiscal-monetary stimulus that was introduced by the authorities in late 2008 and implemented over the subsequent few years. Several observers have seen the stimulus as symbolic of a fundamental shift in government policy, returning to a model of directed lending favouring SOEs (for a summary of these arguments, see Lardy 2012: 11-13). To consider this hypothesis at the firm level, we augment our specifications with a number of dummy variables. First, we augment each specification with a step dummy equal to zero in 2008 and earlier years and equal to one from 2009 onwards ('post-2008 dummy'). We specify a break in 2009 to allow for the change in the aggregate financing environment experienced by firms following the introduction of the stimulus. ${ }^{26}$ Second, to measure the differential effects on state and private firms, we interact this variable with a dummy variable ('state') indicating firm ownership/control (equal to unity if a firm is state owned or controlled). In addition to the above regressors, we include a set of year dummy variables to control for exogenous annual variation affecting all firms. Collectively, the various time dummy variables form the vector $Z_{t}$.

A number of listed companies in our dataset exhibit very unusual leverage behaviour, resulting in very large liabilities-to-assets ratios. This mainly reflects some firms having negative book values for equity at certain points in time, potentially arising from financial distress, which is consistent with the book

24 We experimented with the inclusion of firm age as well, but this variable proved to be insignificant in our specifications.

25 Some studies also use proxies for earnings volatility, but we exclude this variable, as it is difficult to measure with precision in a short time series.

26 We also experimented with including an additional variable measuring growth in the stock of aggregate bank, non-bank and off-balance sheet financing, using data on the national stock of trust loans, entrusted loans and undiscounted bank accepted bills, compiled from net flows published by the PBC. However, our main results were not meaningfully affected by the inclusion of this variable. 
leverage ratios taking on values larger than one. Strategies commonly used in the literature to deal with outliers include censoring the leverage ratio on the unit interval, deleting certain percentiles of the leverage distribution and Winsorisation (for examples, see Byoun 2008; Flannery and Rangan 2006; Lemmon et al. 2008). For our main results, we exclude all firms that experience a liabilities-to-assets ratio in excess of five during the sample period. The reason for admitting firms with leverage ratios greater than unity into the sample is that the non-standard features and unusual values of the leverage distribution are in part what we are trying to explain. However, the key results are not particularly sensitive to censoring on the unit interval (see Appendix 12.1, Table A12.2).

Finally, it is worth noting that we do not use a matched sample of firms for our main set of results. In principle, using a matched sample could bias our results by ignoring compositional change (in particular, the changing relative shares of private and state firms) over the sample period. Against this consideration, it is possible that not using a matched sample could introduce bias due to firm exit and entry over the sample period. Reassuringly, our results are not especially sensitive to whether or not a matched sample is used. Supplementary matched sample results are shown in Appendix 12.1 (Table A12.1).

\section{Results}

The results are displayed in Table 12.8. The static (fixed effects) regression results given in Column 1 suggest that a firm's leverage is negatively correlated with profitability and positively correlated with firm size, collateral, the marketto-book ratio and industry median leverage, controlling for other factors. ${ }^{27}$ The correlation with the non-debt tax shield is insignificant.

Interacting the post-2008 dummy with the ownership dummy, we detect evidence that state ownership increased the liabilities-to-assets ratios of listed companies in the post-2008 period by around 4 percentage points relative to private firms (compared with a median leverage ratio, after excluding outliers, of 45.6 per cent). This suggests that state firms increased their leverage relative to private firms after 2008 by a magnitude exceeding that which could be expected based on normal drivers of leverage decisions at the microeconomic level. However, if firms' leverage decisions are dynamic and persistent over time, the implications of static models may be misleading.

27 We focus on fixed effects rather than random effects as the latter is rejected by a Hausman (1978) test. Chivakul and Lam (2015) present results from a random effects model. Similar to our own results from static models, their results support the hypothesis that state ownership had a positive effect on leverage in the post-2008 period. 
Table 12.8 Determinants of the liabilities-to-assets ratio(a)

\begin{tabular}{|c|c|c|c|}
\hline Variable & Fixed effects (1) & Difference GMM (2) & System GMM (3) \\
\hline Leverage(-1) & & $\begin{array}{r}0.76^{\star \star \star} \\
(0.04)\end{array}$ & $\begin{array}{r}0.83^{\star * *} \\
(0.12)\end{array}$ \\
\hline Profitability & $\begin{array}{r}-0.41^{\star \star \star} \\
(0.11)\end{array}$ & $\begin{array}{r}-0.51^{\star \star \star} \\
(0.14)\end{array}$ & $\begin{array}{l}-0.52 \\
(0.43)\end{array}$ \\
\hline Market-to-book ratio & $\begin{array}{r}0.01^{\star \star \star} \\
(0.00)\end{array}$ & $\begin{array}{r}0.01^{\star * *} \\
(0.00)\end{array}$ & $\begin{array}{r}0.01 \\
(0.00)\end{array}$ \\
\hline Collateral & $\begin{array}{r}0.12^{\star \star \star} \\
(0.04)\end{array}$ & $\begin{array}{l}-0.01 \\
(0.04) \\
\end{array}$ & $\begin{array}{l}-0.01 \\
(0.04)\end{array}$ \\
\hline Non-debt tax shield & $\begin{array}{r}0.68 \\
(0.59) \\
\end{array}$ & $\begin{array}{r}0.01 \\
(0.89) \\
\end{array}$ & $\begin{array}{l}-0.18 \\
(0.81)\end{array}$ \\
\hline Size & $\begin{array}{r}0.07^{\star \star \star} \\
(0.01)\end{array}$ & $\begin{array}{l}0.03^{\star} \\
(0.01)\end{array}$ & $\begin{array}{r}0.03^{\star \star} \\
(0.01)\end{array}$ \\
\hline Industry median & $\begin{array}{r}0.29 * \star \star \\
(0.04)\end{array}$ & $\begin{array}{r}0.23^{\star \star *} \\
(0.03)\end{array}$ & $\begin{array}{r}0.23^{\star \star \star} \\
(0.09)\end{array}$ \\
\hline Post-2008 dummy & $0.01(0.01)$ & $\begin{array}{l}-0.01 \\
(0.02) \\
\end{array}$ & $\begin{array}{l}-0.02 \\
(0.04) \\
\end{array}$ \\
\hline State & & & $\begin{array}{l}-0.06 \\
(0.16)\end{array}$ \\
\hline State $\times$ post-2008 dummy & $\begin{array}{r}0.04^{\star \star \star} \\
(0.01)\end{array}$ & $\begin{array}{l}-0.01 \\
(0.01)\end{array}$ & $\begin{array}{l}-0.01 \\
(0.08)\end{array}$ \\
\hline Constant & $-1.21^{\star \star \star}(0.14)$ & & $\begin{array}{r}-0.50^{*} \\
(0.26)\end{array}$ \\
\hline Observations & 21,285 & 16,832 & 19,191 \\
\hline Firms & 2,444 & 2,172 & 2,323 \\
\hline Hausman test ${ }^{(b)}$ & 0.00 & & \\
\hline Serial correlation(c) & & 0.57 & 0.51 \\
\hline
\end{tabular}

(a) Standard errors in parentheses.

(b) $p$-value for Hausman test of null hypothesis that individual effects are adequately modelled by a random effects model.

(c) p-value for Arellano and Bond (1991) test for second-order serial correlation.

*** significant at the 1 per cent level

** significant at the 5 per cent level

* significant at the 10 per cent level

Notes: The regressions include a set of year dummy variables (not reported). Standard errors are heteroscedasticity consistent and adjusted. In the case of dynamic panel models, robust standard errors are estimated using the procedure described by Windmeijer (2005).

Source: Authors' calculations. 
Columns 2 and 3 of Table 12.8 indicate that some of the variables that are significant in the static regression become insignificant when we allow firm leverage decisions to be correlated over time. This is not entirely surprising, as some of the information about static firm-level determinants of leverage that we observe in the results for the fixed-effects model is already summarised by the lagged dependent variable in the dynamic models. In fact, for several determinants of leverage, the results are quite robust to changes in specification. As in the fixed-effects model, the difference GMM specification finds that leverage displays a significant negative correlation with profitability and is positively correlated with the market-to-book ratio, firm size and industry median leverage, accounting for other factors. ${ }^{28}$ The system GMM model finds firm size and industry median leverage to be significant, but profitability and the market-to-book ratio become insignificant even though they display similar coefficients to those found in the difference GMM specification. ${ }^{29}$ Collateral is found to be insignificant in both models.

Estimates for the interaction between the post-2008 dummy and the ownership dummy diverge from the findings of the static fixed-effects model. The sign of the coefficient on this interaction is reversed but it is insignificant. To check the robustness of this finding, we re-estimated the above models over different periods, with starting periods ranging from 2002 to 2004 and end periods ranging from 2010 to 2015. The results are robust to these variations (see Table A12.3 in Appendix 12.1). Qualitatively similar findings are also found for a matched sample of firms listed since 2000 (see Table A12.1 in Appendix 12.1).

These results suggest that when we control for persistence in leverage, the leverage of state firms relative to private firms after 2008 is not significantly higher than would be predicted based on standard static determinants of capital structure. The change in the coefficient on the interaction term and its significance reflect the transformation of the relationship from levels to changes and also the inclusion of a lagged dependent variable (that is, the shift from Equation 12.3 to Equation 12.6). As the lagged dependent variable already captures differences in prior leverage behaviour between state and private firms, it reduces the ability of the interaction term to detect a significant change in behaviour over and above standard static determinants of leverage.

In both of the dynamic models, the coefficient on lagged leverage is significant, suggesting that a firm's past leverage has an important bearing on current capital structure decisions. The implied speed of adjustment to a hypothetical target leverage ratio is around 24 per cent per annum for the difference GMM model and around 17 per cent for the system GMM model. This suggests an

28 In these specifications, profitability, the market-to-book ratio and collateral are treated as potentially endogenous, and hence second lags of these variables are used as instruments.

29 Profitability is found to be significant and negative in the matched sample specification (see Appendix 13.1). 
approximate half-life of 2.5 to 3.7 years. Our estimate of the speed of adjustment is remarkably similar to that estimated by Qian et al. (2009) for the debt-toassets ratio using a smaller and older sample of firms, who find an adjustment speed of 18.5 per cent per year. ${ }^{30}$ This is much slower than adjustment speeds derived for listed firms in the United States by Flannery and Rangan (2006), who estimate an adjustment speed of 34 per cent per annum in a fixed-effects model (which uses an instrumental variable correction for lagged leverage) and 52 per cent using a difference GMM model.

Overall, the results from our models suggest that, controlling for other factors, a firm's lagged leverage ratio, its size, its profitability and the median leverage of the industry to which it belongs are all helpful in explaining its capital structure decisions. The coefficients on profitability, firm size, the marketto-book ratio and industry median leverage are fairly similar across the three different specifications. The results, combined with the findings of our decomposition of listed company leverage in section three, suggest some reasons for the increase in leverage since the late 2000s. In particular, it is possible that persistence in firm-level leverage behaviour, combined with deteriorating state sector profitability and a compositional shift of listed company assets towards industries such as real estate and construction that display higher average leverage, accounts for much of the upward trend in leverage in recent years. The decomposition in section three indicates that state firms account for the majority of the increase in the leverage of the real estate and construction industries since 2008, although private firms in these industries have also contributed positively to overall leverage.

The fact that some of the most highly leveraged private and state firms have shown signs of deleveraging in the past few years (see section three) could signal a gradual shift towards lower 'target' leverage ratios. Yet if recent trends continue, rising leverage in parts of the private sector and the tendency for more recently listed firms to contribute positively to overall leverage could be counteracting forces. The sustained upward trend in debt and leverage in China is widely perceived by analysts and commentators as a potential precursor to a disruptive financial event or crisis. Should rising leverage eventually result in financial instability that forces an abrupt deleveraging in the corporate sector, it is unlikely that listed companies would be immune. However, if the process of deleveraging proves to be more orderly than this, and if capital structure decisions are highly persistent, as suggested by our model-based estimates, the process of deleveraging for listed firms is likely to be gradual.

30 The speed of adjustment is also robust to estimation over different sample periods, such as those shown in Table A13.3 (Appendix 13.1). 


\section{Concluding remarks}

The rapid build-up in corporate leverage in China since the late 2000s has fuelled concerns about the potential risks for financial stability and growth. Discussions of leverage in China often emphasise the role played by stimulus policies during the GFC in driving up the indebtedness of SOEs. This chapter examines the leverage of a small component of the broader Chinese corporate universe - non-financial companies listed on mainland public exchanges - to obtain a more granular picture of how leverage patterns have evolved in recent years, particularly since the late 2000s.

Our analysis supports the view that state-owned or state-controlled firms have led the rise in corporate leverage, and that these firms have seen a corresponding deterioration in operating performance relative to private firms since the stimulus period. As the bulk of listed company assets are controlled or owned by state entities, state firms continue to account for the lion's share of overall leverage. However, this broad picture masks considerable heterogeneity at a more disaggregated level.

On the one hand, there is evidence of deleveraging among some of the more highly leveraged private and state firms. On the other hand, the rising share of listed company assets in private hands and pockets of increasing private sector leverage (especially firms that have entered the sample since 2008) mean that the private sector has accounted for a greater share of the increase in listed company leverage than average leverage ratios for state and private firms might suggest. By industry, real estate and construction firms have contributed the most to the pick-up in leverage, while utilities, mining and services firms have subtracted overall. Private firms have tended to contribute positively to the increase in leverage since 2012, particularly in manufacturing and services industries.

Results from fixed-effects panel regressions of leverage on key firm-level determinants point to a negative association between leverage and profitability and a positive correlation with firm size, collateral and industry leverage patterns. Dynamic models, which allow for leverage decisions to be serially correlated, further indicate that persistence in capital structure decisions at the firm level is an important feature of observed leverage behaviour. It is possible that this characteristic, combined with weaker state-sector profitability and a shift in industry composition towards more highly leveraged sectors such as real estate and construction in the wake of the government's 2008-09 stimulus, explains much of the upward trend in leverage over recent years. If this is correct, and true for non-listed companies as well, sluggish adjustment in firm behaviour could make it challenging for China's corporate sector to achieve rapid deleveraging. 


\section{References}

Arellano, M. and Bond, S. (1991), Some tests of specification for panel data: Monte Carlo evidence and an application to employment equations, Review of Economic Studies, 58: 277-297.

Bank for International Settlements (BIS) (2016), Long series on credit to the private non-financial sector, Online database, Bank for International Settlements, Basel. Available from: bis.org/statistics/credtopriv.htm.

Blundell, R. and Bond, S. (1998), Initial conditions and moment restrictions in dynamic panel data models, Journal of Econometrics, 87: 115-143.

Borio, C. and Lowe, P. (2002), Asset prices, financial and monetary stability: Exploring the nexus, BIS Working Paper No. 114, Basel: Bank for International Settlements.

Byoun, S. (2008), How and when do firms adjust their capital structures toward targets?, Journal of Finance, 108(6): 2069-3096.

Chen, G., Firth, M. and Xu, L. (2009), Does the type of ownership control matter? Evidence from China's listed companies, Journal of Banking and Finance, 33: $171-181$.

Chen, J. (2004), Determinants of capital structure of Chinese-listed companies, Journal of Business Research, 57: 1341-1351.

Chen, L. (2014), The future history of China's deleveraging, Gavekal Dragonomics, July.

Chivakul, M. and Lam, W. R. (2015), Assessing China's corporate sector vulnerabilities, IMF Working Paper No. WP/15/72, Washington, DC: International Monetary Fund.

Ding, Y. and Su, X. (2008), Implementation of IFRS in a regulated market, Journal of Accounting and Public Policy, 27: 474-479.

Donaldson, G. (1961), Corporate debt capacity: A study of corporate debt policy and the determination of corporate debt capacity, Cambridge, Mass.: Harvard Business School.

Drehmann, M. and Juselius, M. (2013), Evaluating early warning indicators of banking crises: Satisfying policy requirements, BIS Working Paper No. 421, Basel: Bank for International Settlements. 
Fan, J. P. H., Wong, T. J. and Zhang, T. (2007), Politically connected CEOs, corporate governance and post-IPO performance in China's newly partially privatized firms, Journal of Financial Economics, 84: 300-357.

Firth, M., Malatesta, P. H., Xin, Q. and Xu, L. (2012), Corporate investment, government control, and financing channels: Evidence from China's listed companies, Journal of Corporate Finance, 18: 433-450.

Flannery, M. J. and Hankins, K. W. (2013), Estimating dynamic panel models in corporate finance, Journal of Corporate Finance, 19: 1-19.

Flannery, M. J. and Rangan, K. P. (2006), Partial adjustment toward target capital structures, Journal of Financial Economics, 79: 469-506.

Frank, M. Z. and Goyal, V. K. (2009), Capital structure decisions: Which factors are reliably important?, Financial Management, 38: 1-37.

Harris, M. and Raviv, A. (1991), The theory of capital structure, Journal of Finance, 46: 297-355.

Hausman, J. A. (1978), Specification tests in econometrics, Econometrica, 46: $1251-1271$.

Holtz-Eakin, D., Newey, W. and Rosen, H. S. (1988), Estimating vector autoregressions with panel data, Econometrica, 56: 1371-1395.

Huang, S. G. H. and Song, F. M. (2006), The determinants of capital structure: Evidence from China, China Economic Review, 17: 14-35.

Huang, Y. and Bosler, C. (2014), China's debt dilemma: Deleveraging while generating growth, Paper, 18 September, Beijing: Carnegie Endowment for International Peace. Available from: carnegieendowment.org/2014/09/18/ china-s-debt-dilemma-deleveraging-while-generating-growth.

International Monetary Fund (IMF) (2015a), People's Republic of China, Article IV consultation, IMF Country Report No. 15/234. Available from: imf.org/ external/pubs/ft/scr/2015/cr15234.pdf.

International Monetary Fund (IMF) (2015b), Global Financial Stability Report: Vulnerabilities, Legacies and Policy Challenges - Risks Rotating to Emerging Markets, October 2015: 12. Available from: imf.org/External/Pubs/FT/ GFSR/2015/02/pdf/text.pdf.

Lardy, N. (1998), China's unfinished economic revolution, Washington, DC: Brookings Institution.

Lardy, N. (2012), Sustaining China's economic growth after the Global Financial Crisis, Washington, DC: Institute for International Economics. 
Lemmon, M. L., Roberts, M. R. and Zender, J. F. (2008), Back to the beginning: Persistence and the cross-section of corporate capital structure, Journal of Finance, 118(4): 1575-1607.

Li, K., Yue, H. and Zhao, L. (2009), Ownership, institutions and capital structure: Evidence from China, Journal of Comparative Economics, 37(3): 471-490.

Myers, S. (1984), The capital structure puzzle, Journal of Finance, 39: 575-592.

Myers, S. and Majluf, N. (1984), Corporate financing and investment decisions when firms have information that investors do not have, Journal of Financial Economics, 13: 187-221.

National Development and Reform Commission (NDRC) (2016), Report on the implementation of the 2015 Plan for National Economic and Social Development and on the 2016 Draft Plan for National Economic and Social Development, Beijing: NDRC. Available from: online.wsj.com/public/resources/documents/ NPC2016_NDRC_English.pdf.

Nickell, S. (1981), Biases in dynamic models with fixed effects, Econometrica, 49: 1417-1426.

People's Bank of China (PBC) (2016), Transcript of Governor Zhou's Xiaochuan's press conference, Beijing, 10 March. Available from: pbc.gov.cn/ english/130721/3029330/index.html.

Pettis, M. (2013), Avoiding the fall: China's economic restructuring, Washington, DC: Carnegie Endowment for International Peace.

Qian, Y., Tian, Y. and Wirjanto, T. S. (2009), Do Chinese publicly listed companies adjust their capital structure toward a target level?, China Economic Review, 20: $662-676$.

Walter, C. E. and Howie, F. J. T. (2011), Red capitalism: The fragile financial foundations of China's extraordinary rise, Singapore: John Wiley \& Sons.

Windmeijer, F. (2005), A finite sample correction for the variance of linear efficient two-step GMM estimators, Journal of Econometrics, 126: 25-51.

Yu, M. (2013), State ownership and firm performance: Empirical evidence from Chinese listed companies, China Journal of Accounting Research, 6: 75-87.

Zhang, W., Han, G., Ng, B. and Chan, S. (2015), Corporate leverage in China: Why has it increased fast in recent years and where do the risks lie?, Working Paper No. 10/15, Hong Kong: Hong Kong Institute for Monetary Research. 


\section{Appendix 12.1: Supplementary regression results}

Table A12.1 Determinants of the liabilities-to-assets ratio: Matched sample ${ }^{(a)}$

\begin{tabular}{|c|c|c|c|}
\hline Variable & Fixed effects (1) & Difference GMM (2) & System GMM (3) \\
\hline Leverage(-1) & & $\begin{array}{r}0.78^{\star \star \star} \\
(0.03)\end{array}$ & $\begin{array}{r}0.83^{\star \star \star} \\
(0.03)\end{array}$ \\
\hline Profitability & $\begin{array}{r}-0.37^{\star \star \star} \\
(0.11)\end{array}$ & $\begin{array}{r}-0.39^{\star \star \star} \\
(0.13)\end{array}$ & $\begin{array}{r}-0.43^{\star \star \star} \\
(0.13)\end{array}$ \\
\hline Market-to-book ratio & $\begin{array}{c}0.01^{\star \star} \\
(0.01)\end{array}$ & $\begin{array}{r}0.01^{\star \star \star} \\
(0.00)\end{array}$ & $\begin{array}{r}0.00 \\
(0.00) \\
\end{array}$ \\
\hline Collateral & $\begin{array}{r}0.06 \\
(0.04)\end{array}$ & $\begin{array}{l}-0.05 \\
(0.04)\end{array}$ & $\begin{array}{l}-0.04 \\
(0.04)\end{array}$ \\
\hline Non-debt tax shield & $\begin{array}{r}0.67 \\
(0.61) \\
\end{array}$ & $\begin{array}{l}-0.23 \\
(0.52)\end{array}$ & $\begin{array}{r}0.26 \\
(0.81) \\
\end{array}$ \\
\hline Size & $\begin{array}{r}0.06^{\star \star \star} \\
(0.01)\end{array}$ & $\begin{array}{r}0.01 \\
(0.64)\end{array}$ & $\begin{array}{r}0.02^{\star \star \star} \\
(0.01)\end{array}$ \\
\hline Industry median & $\begin{array}{r}0.28^{\star \star \star} \\
(0.05)\end{array}$ & $\begin{array}{r}0.21^{\star \star \star} \\
(0.04)\end{array}$ & $\begin{array}{r}0.19^{\star \star \star} \\
(0.05)\end{array}$ \\
\hline Post-2008 dummy & $\begin{array}{r}-0.03^{*} \\
(0.02)\end{array}$ & $\begin{array}{l}0.02^{*} \\
(0.01)\end{array}$ & $\begin{array}{r}0.02 \\
(0.01)\end{array}$ \\
\hline State & & & $\begin{array}{r}0.02 \\
(0.04) \\
\end{array}$ \\
\hline State $\times$ post-2008 dummy & $\begin{array}{r}0.07^{\star \star *} \\
(0.01)\end{array}$ & $\begin{array}{l}-0.01 \\
(0.01)\end{array}$ & $\begin{array}{l}-0.01 \\
(0.01)\end{array}$ \\
\hline Constant & $\begin{array}{r}-1.01^{\star \star \star} \\
(0.19) \\
\end{array}$ & & $\begin{array}{r}-0.47^{\star \star \star} \\
(0.10)\end{array}$ \\
\hline Observations & 11,685 & 10,028 & 10,899 \\
\hline Firms & 839 & 787 & 839 \\
\hline Hausman test ${ }^{(b)}$ & 0.00 & & \\
\hline Serial correlation ${ }^{(c)}$ & & 0.45 & 0.39 \\
\hline
\end{tabular}

(a) Standard errors in parentheses.

(b) $p$-value for Hausman test of null hypothesis that individual effects are adequately modelled by a random effects model.

(c) p-value for Arellano and Bond (1991) test for second-order serial correlation

*** significant at the 1 per cent level

** significant at the 5 per cent level

* significant at the 10 per cent level

Notes: The regressions include a set of year dummy variables (not reported). Standard errors are heteroscedasticity consistent and adjusted. In the case of dynamic panel models, robust standard errors are estimated using the procedure described by Windmeijer (2005).

Source: Authors' calculations. 
Table A12.2 Determinants of the liabilities-to-assets ratio (censored on unit interval)(a) $^{(a)}$

\begin{tabular}{|c|c|c|c|}
\hline Variable & Fixed effects (1) & Difference GMM (2) & System GMM (3) \\
\hline Leverage $(-1)$ & & $\begin{array}{r}0.75^{\star \star \star} \\
(0.28)\end{array}$ & $\begin{array}{r}0.81^{\star \star *} \\
(0.05)\end{array}$ \\
\hline Profitability & $\begin{array}{r}-0.51^{\star \star \star} \\
(0.02)\end{array}$ & $\begin{array}{r}-0.17^{\star} \\
(0.09)\end{array}$ & $\begin{array}{l}-0.25 \\
(0.63)\end{array}$ \\
\hline Market-to-book ratio & $\begin{array}{l}-0.00 \\
(0.00)\end{array}$ & $\begin{array}{r}0.01^{* * \star} \\
(0.00)\end{array}$ & $\begin{array}{r}0.00 \\
(0.00)\end{array}$ \\
\hline Collateral & $\begin{array}{r}0.11^{\star * *} \\
(0.02)\end{array}$ & $\begin{array}{r}0.02 \\
(0.02)\end{array}$ & $\begin{array}{r}0.02 \\
(0.05)\end{array}$ \\
\hline Non-debt tax shield & $\begin{array}{r}-0.43^{\star \star \star} \\
(0.14)\end{array}$ & $\begin{array}{l}-0.87 \\
(0.22)\end{array}$ & $\begin{array}{r}-0.98^{\star *} \\
(0.42)\end{array}$ \\
\hline Size & $\begin{array}{r}0.09^{\star \star *} \\
(0.00) \\
\end{array}$ & $\begin{array}{r}0.05^{\star \star \star} \\
(0.01) \\
\end{array}$ & $\begin{array}{r}0.02^{\star \star \star} \\
(0.01) \\
\end{array}$ \\
\hline Industry median & $\begin{array}{r}0.19^{\star \star \star} \\
(0.03)\end{array}$ & $\begin{array}{r}0.24^{\star \star \star} \\
(0.03)\end{array}$ & $\begin{array}{r}0.23^{\star \star \star} \\
(0.07)\end{array}$ \\
\hline Post-2008 dummy & $\begin{array}{l}-0.01 \\
(0.01)\end{array}$ & $\begin{array}{l}-0.01 \\
(0.01)\end{array}$ & $\begin{array}{l}-0.02 \\
(0.04) \\
\end{array}$ \\
\hline State & & & $\begin{array}{l}-0.03 \\
(0.11) \\
\end{array}$ \\
\hline State $\times$ post-2008 dummy & $\begin{array}{r}0.02^{\star \star \star} \\
(0.01)\end{array}$ & $\begin{array}{l}-0.01 \\
(0.01)\end{array}$ & $\begin{array}{l}-0.01 \\
(0.01)\end{array}$ \\
\hline Constant & $\begin{array}{r}-1.49^{\star \star \star} \\
(0.11)\end{array}$ & & $\begin{array}{r}-0.44^{\star \star \star} \\
(0.08)\end{array}$ \\
\hline Observations & 20,197 & 15,934 & 18,183 \\
\hline Firms & 2,353 & 2,091 & 2,232 \\
\hline Hausman test ${ }^{(b)}$ & 0.00 & & \\
\hline Serial correlation ${ }^{(c)}$ & & 0.96 & 0.99 \\
\hline
\end{tabular}

(a) Standard errors in parentheses.

(b) $p$-value for Hausman test of null hypothesis that individual effects are adequately modelled by a random effects model.

(c) p-value for Arellano and Bond (1991) test for second-order serial correlation.

*** significant at the 1 per cent level

** significant at the 5 per cent level

* significant at the 10 per cent level

Notes: The regressions include a set of year dummy variables (not reported). Standard errors are heteroscedasticity consistent and adjusted. In the case of dynamic panel models, robust standard errors are estimated using the procedure described by Windmeijer (2005).

Source: Authors' calculations. 
China's New Sources of Economic Growth (I)

Table A12.3 Sample sensitivity: Coefficient on state $\times$ post-2008 dummy ${ }^{(a)}$

\begin{tabular}{|l|c|c|c|}
\hline Sample & Fixed effects & Difference GMM & System GMM \\
\hline $2000-15$ & $0.04^{\star \star \star}$ & -0.01 & -0.01 \\
\hline $2001-15$ & $0.04^{\star \star \star}$ & -0.01 & -0.01 \\
\hline $2002-15$ & $0.04^{\star \star \star}$ & -0.01 & -0.01 \\
\hline $2003-15$ & $0.04^{\star \star \star}$ & -0.01 & -0.01 \\
\hline $2004-15$ & $0.04^{\star \star *}$ & -0.01 & -0.00 \\
\hline $2000-14$ & $0.04^{\star \star *}$ & -0.01 & -0.01 \\
\hline $2000-13$ & $0.04^{\star \star *}$ & -0.01 & -0.01 \\
\hline $2000-12$ & $0.03^{\star \star *}$ & -0.01 & -0.01 \\
\hline $2000-11$ & $0.03^{\star \star *}$ & -0.01 & -0.01 \\
\hline $2000-10$ & $0.02^{\star \star}$ & -0.01 & -0.01 \\
\hline
\end{tabular}

(a) Standard errors in parentheses.

*** significant at the 1 per cent level

** significant at the 5 per cent level

* significant at the 10 per cent level

Notes: Standard errors are heteroscedasticity consistent and adjusted. Windmeijer (2005) robust standard errors are used for dynamic panel models.

Source: Authors' calculations. 
This text is taken from China's New Sources of Economic Growth: Reform, resources and climate change, Volume 1, edited by Ligang Song, Ross Garnaut, Cai Fang \& Lauren Johnston, published 2016 by ANU Press, The Australian National University, Canberra, Australia. 